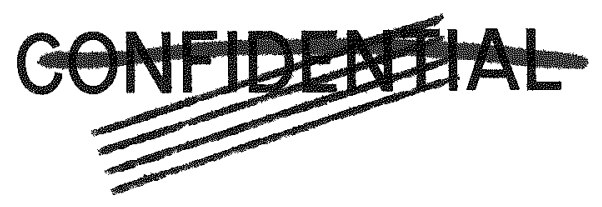

This document consists of 51 pages

No. 251 of 345 copies, Series A

Report to the Test Director

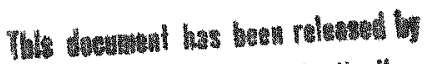
the Division of Mutary Applisation

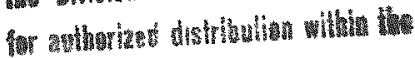

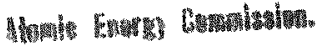

\title{
EFFECTS OF AN ATOMIC EXPLOSION ON UNDERGROUND AND BASEMENT TYPES OF HOME SHELTERS
}

By

Joseph B. Byrnes
This document is PUBLICLY RELAASADLE

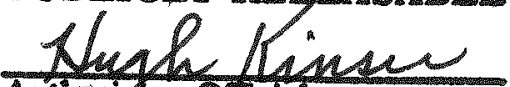
Authorifag Oticial

Dete:
Approved by: ROBERT L. CORSBIE

Director

Civil Effects Test Group

Federal Civil Defense Administration

Washington, D. C.

October 1953
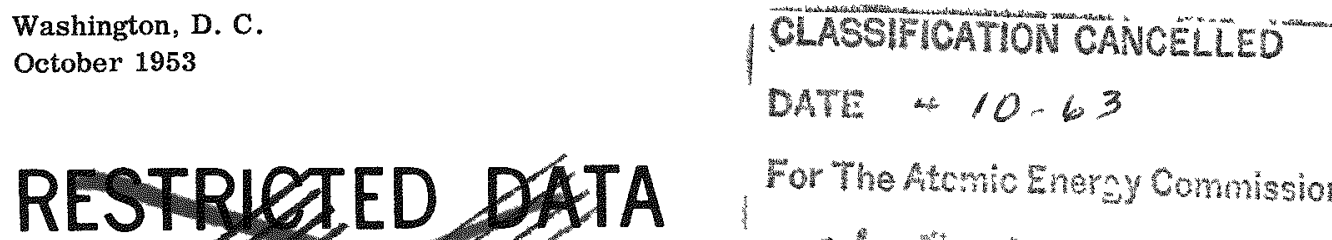

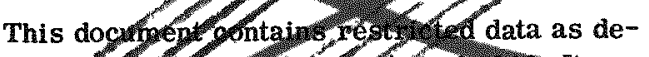

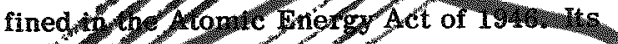
tranoty the disolgstire of its contents in anfytpotiner to an unathorized person is prohibfted.

For The Aftcmic Enery Commission

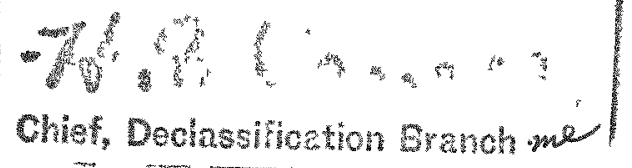




\section{DISCLAIMER}

This report was prepared as an account of work sponsored by an agency of the United States Government. Neither the United States Government nor any agency Thereof, nor any of their employees, makes any warranty, express or implied, or assumes any legal liability or responsibility for the accuracy, completeness, or usefulness of any information, apparatus, product, or process disclosed, or represents that its use would not infringe privately owned rights. Reference herein to any specific commercial product, process, or service by trade name, trademark, manufacturer, or otherwise does not necessarily constitute or imply its endorsement, recommendation, or favoring by the United States Government or any agency thereof. The views and opinions of authors expressed herein do not necessarily state or reflect those of the United States Government or any agency thereof. 


\section{DISCLAIMER}

Portions of this document may be illegible in electronic image products. Images are produced from the best available original document. 


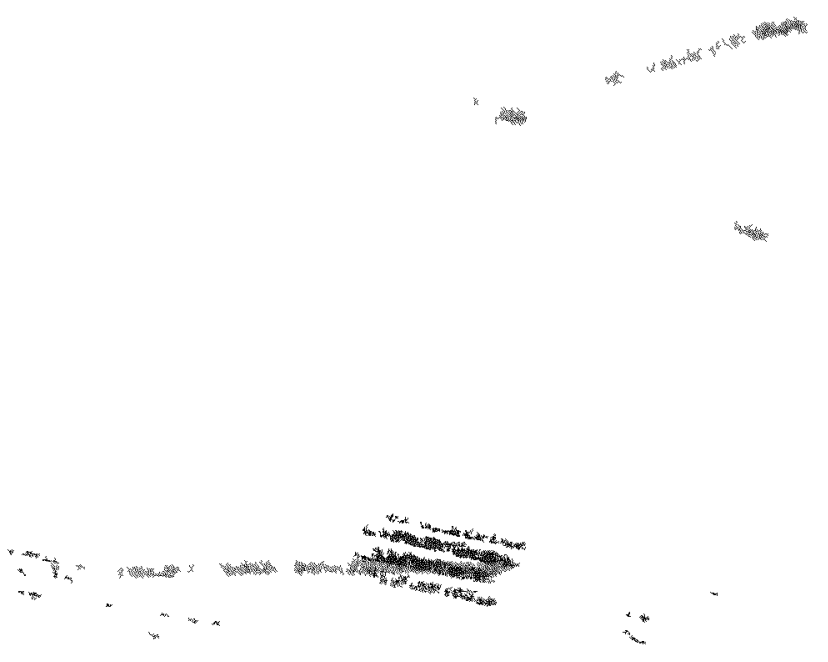




\section{ABSTRACT}

This joint FCDA-AEC project was conducted to check the adequacy of several proposed home shelter designs.

Underground earth-covered shelters were exposed to a 16.4-kt, 300-ft tower shot at ranges of $1230 \mathrm{ft}$ (one), $1450 \mathrm{ft}$ (one), $1800 \mathrm{ft}$ (five), and $3500 \mathrm{ft}$ (one). Two types of basement shelters were constructed in each of the test houses at 3500 and $7500 \mathrm{ft}$ (Project 21.2).

Instrumentation was by gamma-radiation badges, paraffin cubes, and nylon swatches. Attempts were made to measure permanent deflections of concrete roof slabs. Mannequins were placed in several shelters for purposes of demonstration and observation of blast-caused movement.

A weighted mannequin in the underground shelter at $1230 \mathrm{ft}$ was broken in half; an unweighted one (child size) was thrown to the floor. All other mannequins remained in place, undamaged. Paraffin cubes and nylon swatches showed no evidence of thermal damage. Fallout conditions made it impossible to determine initial gamma-radiation quantities. There was no cracking or permanent deflection of the concrete roof slabs. Except for a wood-covered, trench type shelter, which partially failed because of faulty construction, the shelters showed no blast damage.

Thermal energy entering the shelters probably would not have caused skin burns to human occupants.

Adequacy of the shelters under full design loads could not be determined because pressures were lower than expected, but the shelter designs were structurally acceptable under test pressures received. Future tests are required under higher pressures. The basement shelters should be tested under masonry debris loads.

$3-4$

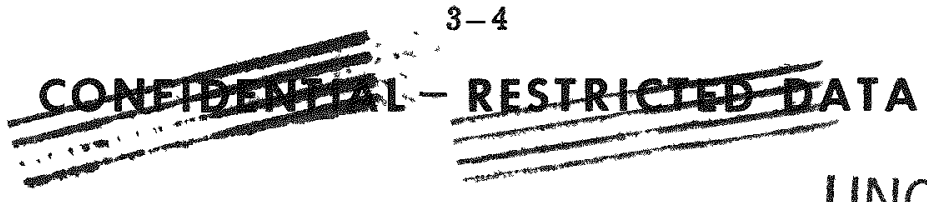




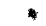

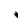




\section{UNCLASSIFIED}

\section{ACKNOWLEDGMENTS}

L. A. Darling Company of Bronson, Mich., loaned, without charge to the Federal Civil Defense Administration (FCDA), all department-store mannequins used in the shelters.

North American Van Lines transported mannequins to and from Las Vegas, Nev., without cost to FCDA.

The Atlas Trucking Company of Las Vegas, as a public service, hauled mannequins to and from the Nevada Proving Grounds.

The J. C. Penney Company of Las Vegas, through the National Retail Dry Goods Association, donated clothing and dressed all mannequins used in this test.

The film and film holders used in the measurement of the gamma-radiation dose were supplied by the Radiation Instruments Branch of the U. S. Atomic Energy Commission, and the films were processed and read at the National Bureau of Standards.

Jack C. Greene of the Health and Special Weapons Defense Office of FCDA assembled and supervised the placing of the badges and interpreted the film readings.

Benjamin C. Taylor, Director of the Technical Division, and A. S. Neiman of FCDA reviewed this report. 
○

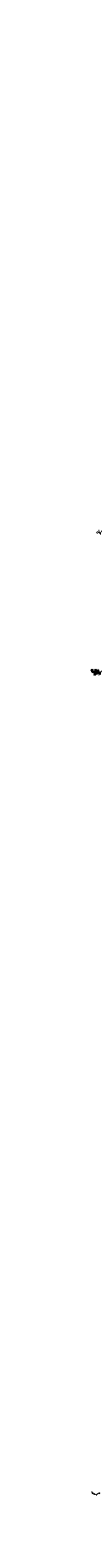

- 


\title{
CONTENTS
}

\author{
ABSTRACT
}

ACKNOWLEDGMENTS

1 INTRODUCTION.

1.1 Objective

1.2 Background

1.3 Instrumentation .

2 TEST RESULTS .

2.1 Gamma-radiation Penetration

2.2 Thermal-radiation Effects.

2.3 Blast Effects

3 DISCUSSION

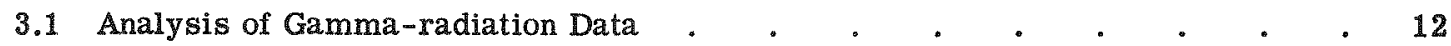

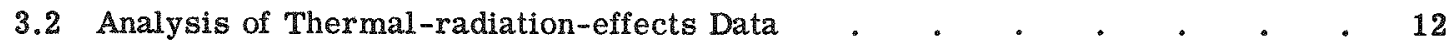

3.3 Analysis of Blast-effects Data . . . . . . . . . . . . $\quad$. 12

3.4 Conclusions . . . . . . . . . . . . . . . . . 13

3.5 Recommendations . . . . . . . . . . . . . . . . . $\quad . \quad 13$

APPENDIX LOCATIONS AND STRUCTURAL DETAILS OF SHELTERS. . . - 35

\section{ILLUSTRATIONS}

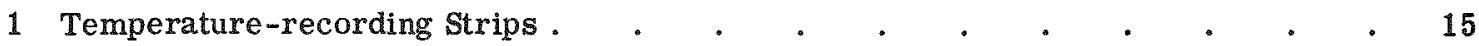

2 Reinforced Concrete Basement Exit Before Blast . . . . . . . . . 16

3 Reinforced Concrete Basement Exit After Blast $\quad . \quad$. $\quad . \quad$. $\quad . \quad$. $\quad . \quad 17$

4 Entrance to Reinforced Concrete Basement Exit After Blast . . . . . 18

5 Entrance to Covered Trench at $1800 \mathrm{Ft}$ Before Blast.$\quad$. $\quad . \quad$. $\quad . \quad$. 19

6 Shaft Entrance to Wood-covered Trench Before Blast . . . . . $\quad 20$

7 Shaft Entrance to Wood-covered Trench After Blast . . . . . . . . 21

8 Blast Damage to Wood-covered Trench . . . . . . . . . $\quad 22$

9 Closed Entrance to Covered Trench Before Blast . . . . . . . . $\quad 23$

10 Entrance to Block-wall Basement Exit Before Blast . . . . . . 24

11 Entrance to Block-wall Basement Exit After Blast . . . . . . . 25

12 Shaft Entrance to Concrete Pipe Before Blast . . . . . . . . 26 


\section{ILLUSTRATIONS (Continued)}

13 Covered Trench at $3500 \mathrm{Ft}$ Before Blast . . . . . . . . . . . . 27

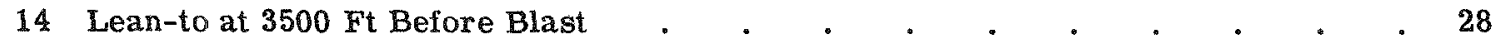

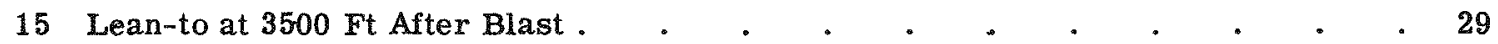

16 Lean-to at $7500 \mathrm{Ft}$ Before Blast . . . . . . . . . . . . . . $\quad$. 30

17 Basement Corner Room at $3500 \mathrm{Ft}$ Before Blast . . . . . . . . . 31

18 Basement Corner Room at $7500 \mathrm{Ft}$ Before Blast . . . . . . . . $\quad 32$

19 Basement Corner Room at $7500 \mathrm{Ft}$ After Blast. . . . . . . . . . 33

20 Damage to Basement Corner Room at $3500 \mathrm{Ft}$. . . . . . . . . 34

A.1 Location Plan . . . . . . . . . . . . . . . . . . 37

A.2 Reinforced Concrete Basement Exit . . . . . . . . . . . . 38

A.3 Covered Trench at 1450,1800 , and $3500 \mathrm{Ft}$. $\quad . \quad$. $\quad . \quad$. $\quad . \quad$. $\quad$. 39

A.4 Wood-covered Trench . . . . . . . . . . . . . . . . . 40

A.5 Covered Trench with Closed Shaft Entrance . . . . . . . . . $\quad$. 41

A.6 Block-wall Basement Exit . . . . . . . . . . . . . . . . . 42

A.7 Concrete Pipe with Closed Shaft Entrance . . . . . . . . . . . . 43

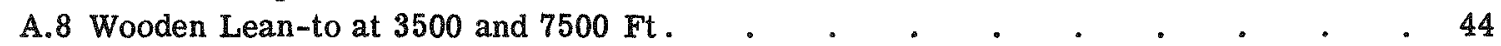

A.9 Basement Corner Room at 3500 and $7500 \mathrm{Ft}$. $\quad . \quad$. $\quad . \quad$. $\quad . \quad$. $\quad$. 45 


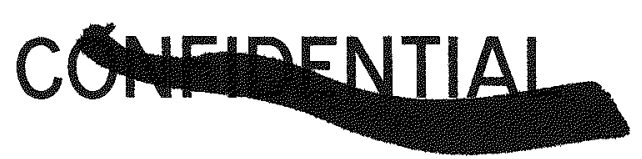

\section{EFFECTS OF AN ATOMIC EXPLOSION ON UNDERGROUND AND BASEMENT TYPES OF HOME SHELTERS}

\section{INTRODUCTION}

\subsection{Objective}

Eight outdoor and four indoor home type shelters, located at various distances from Ground Zero (Fig. A.1), were constructed at the Nevada Proving Grounds (NPG) and exposed to a 16.4-kt atomic device exploded at an altitude of $300 \mathrm{ft}$ (Operation Upshot-Knothole, shot 1). The purpose of the test was to check the adequacy of several types of home shelters, proposed by the Federal Civil Defense Administration (FCDA), against gamma-radiation penetration and thermal and blast effects.

\subsection{Background}

Several types of home shelters, designed by Lehigh University Institute of Research for FCDA, were tested in the Buster series of October and November 1951, and the results were reported. ${ }^{1}$ These tests showed weaknesses in the entrances. Since many of the underground shelters were constructed of wood which would have a comparatively short life in many parts of the United States, it was decided to use building materials of a more permanent nature. The covered trench was redesigned with reinforced concrete-block walls and with wood and concrete roofs; the basement corner room, the block-wall basement exit, and the concrete pipe were added as new types; and the Lehigh lean-to was modified for attachment to the basement wall. The Lehigh design for the reinforced concrete basement exit was selected as the most blast resistant. Since a manual on home shelters was being prepared, a field test of these shelters was considered necessary.

\subsection{Instrumentation}

No funds were available for instrumentation, and consequently it was necessary to improvise in an effort to determine thermal and blast effects. Eight gamma-radiation film badges were placed in each of the underground shelters, five in each of the two basement corner rooms, and two in each of the two lean-to's. Badges were attached to the walls of the shelters by nailing through adhesive tape slings or taping to studs driven into the concrete. Locations and total doses recorded by badges and distances of the shelters from Ground Zero are shown in Fig. A.1.

One treated-paper temperature-recording strip, mounted on 4 - by $5-$ by $3 / 16^{-i n}$. plywood and furnished by the Quartermaster Research and Development Laboratory of Philadelphia, Pa., was nailed to the top of the bench in the reinforced concrete basement exit at $1230 \mathrm{ft}$ from

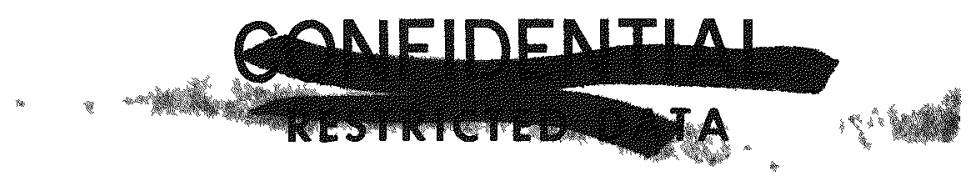


Ground Zero; one was nailed to the top of the bench in the covered trench at $1450 \mathrm{ft}$ from Ground Zero; and one was natled to the top the bench in the covered trench at $1800 \mathrm{ft}$ from Ground Zero. These calibrated strips, white to gray in color, turn black when the temperature for which they are designed is reached (Fig. 1).

Half-inch cubes of ordinary household paraffin were mounted on $2-$ by $2-$ by $3 / 4-i n$. wood blocks by means of a brad through the center. Olive drab nylon cloth swatches 6 by 6 in., donated by the Quartermaster Research and Development Laboratory, were mounted with tacks to $7 \frac{1}{2}-$ by $7 \frac{1}{2}$ - by $3 / 4$-in. wood blocks. One nylon and one paraffin sample were placed in each of the two lean-to's and in each of the two corner rooms. Three nylon and three paraffin samples were attached to the walls in the reinforced concrete basement exit and in the covered trench at $1800 \mathrm{ft}$. Two nylon and two paraffin samples were attached to the walls in the covered trench at $1450 \mathrm{ft}$. (See Fig. A.1.) The critical energy of the paraffin was estimated to be smaller than the 3 calories per square centimeter per second for the nylon cloth, but the actual value was to be determined later.

Attempts were made to measure permanent deflection of the concrete roof slabs in the reinforced concrete basement exit, in the covered trench at $1450 \mathrm{ft}$, and in the covered trenches at $1800 \mathrm{ft}$. A solid Monel wire, $0.020 \mathrm{in}$. in diameter, with one end connected to a small bolt and the other end attached to a $1 \frac{1}{2}-\mathrm{lb}$ sash weight was used as a reference line for measuring deflection. This wire was detachable and was used in the shelters before and after the blast. The bolt end of the wire was threaded through a $3 / 8$-in. tiller guide, attached to the wall on one side, across the shelter, and through a flanged eye attached to the opposite wall at the middle of the shelter. The center point of the span on the bottom of the slab directly over the wire was marked. A steel scale graduated to $1 / 64$ in. was used to measure vertical distances from the center points to the wire.

\section{TEST RESULTS}

\subsection{Gamma-radiation Penetration}

At 5:20 A.M. on Mar. 17, 1953, the 16.4-kt device was detonated from the top of a $300-\mathrm{ft}$ tower. Early reports by monitors indicated a heavy radioactive fall-out along a radial line from Ground Zero through the houses and shelters. Postoperation plans called for the entry of a recovery party at 7:30 A.M. Because of the high radiation level, postoperation plans were changed, and film badges in the basement shelters at $7500 \mathrm{ft}$ were collected at 12:30 P.M. At noon on Mar. 18 , 1953, a recovery party recovered badges in the basement shelters at $3500 \mathrm{ft}$ and in all underground shelters except the wood-covered trench and the concrete pipe. Badges in the wood-covered trench were picked up at 12:15 P.M. on Mar. 20, 1953. No badges were recovered in the concrete pipe. Total gamma dosages are shown in Fig. A.1.

\subsection{Thermal-radiation Effects}

None of the paper temperature-recording strips turned black. There was no evidence that the nylon cloth swatches had melted. The paraffin cubes retained their sharp edges and showed no signs of melting, although some of them in the underground shelters changed in color to that of the surrounding soil, presumably caused by embedded dust.

\subsection{Blast Effects}

(a) Reinforced Concrete Basement Exit. For construction details of this shelter see Fig. A.2. Figure 2 shows the interior of the reinforced concrete basement exit at $1230 \mathrm{ft}$ from Ground Zero. Sand weighing $28 \mathrm{lb}$ was poured into the lower hollow half of the mannequin through an opening in the back at approximately waist level. Total dummy weight was about $60 \mathrm{lb}$. A child mannequin, weighing $7 \mathrm{lb}$, is not visible in the photograph. Gamma-radiation badges, nylon swatches, and paraffin cubes are shown in the background.

Figure 3 shows the same interior after the blast. The 2- by 12-in. leg of the bench near the entrance was removed by the blast. The child mannequin was undamaged, although thrown

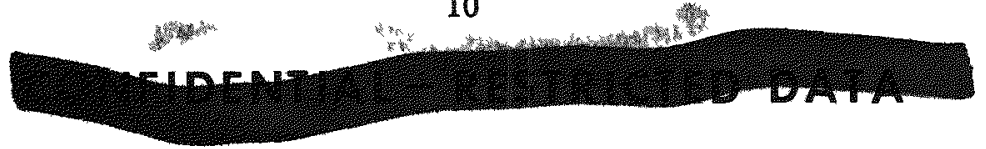


to the floor and partially covered with sand. The female mannequin was separated in two parts by the breaking of a wood dowel pin at the waist, used to connect the upper and lower parts.

Figure 4 shows the entrance to the reinforced concrete basement exit after the blast. A $1 / 16^{-i n}$. separation, not visible in the photograph, between the concrete steps and left entrance wall extended from the grade to the shelter floor. No other damage to the shelter was observed.

The roof slab showed no cracks. Measurements taken before and after the blast showed no permanent deflection of the roof slab.

(b) Covered Trench Shelter at 1450 Ft from Ground Zero. See Fig. A.3 for details of this shelter. Thirty-three pounds of sand was added to the lower part of the male mannequin in this shelter in the same manner as previously described. The total weight of the mannequin, fully clothed, was $84 \mathrm{lb}$. Marks were made on the bench and roof slab of the shelter before the blast to locate the position of the dummy.

The mannequin was not moved or damaged by the blast. No damage to the shelter was evident. The roof slab showed no cracks and had no permanent deflection at midspan.

(c) Covered Trench Shelter at 1800 Ft from Ground Zero. See Fig. A.3 for details of this shelter. Figure 5 shows the entrance to the covered trench shelter at $1800 \mathrm{ft}$ from Ground Zero before the blast. Since no damage to the exterior occurred, the after-blast photograph was omitted.

The total weight of the male mannequin, fully clothed and with sand in the lower parts, was $84 \mathrm{lb}$. Marks were made on the bench and roof slab, as before, to locate the initial beforeblast position of the mannequin.

The mannequin was not moved or damaged by the blast. No damage to the shelter was observed. The roof showed no cracks. Permanent deflection of the center of the slab measured $1 / 16$ in., but this may have been due to the limitations of accuracy of the method used.

(d) Wood-covered Trench Shelter at 1800 Ft from Ground Zero. For drawing of this wood-covered trench see Fig. A.4. Figure 6 shows the experimental shaft entrance to the wood-covered trench before the blast. Figure 7 shows the damage to the shaft entrance after the blast. This entrance was constructed only as a means of access to the shelter for test personnel and was not under test. Figure 7 is of interest, however, because it shows the movement of the bottom of the wall inward, probably due to the additional load resulting from the blast.

Figure 8 shows the failure of one of the longitudinal side walls of this shelter after the blast. The break occurred about midway between the end wall and the entrance. In Figure A.4 the roof joists are shown bearing on a 2 - by 6 -in. plate. This plate was to be attached to the block walls with $1 / 2$-in. round bolts about $2 \mathrm{ft} 0$ in. on center. Because of a misunderstanding of the drawing during construction, the plate was attached to the walls with a total of four bolts only, one near each corner. The roof joists suffered no damage.

(e) Covered Trench Shelter with Closed Shaft Entrance at $1800 \mathrm{Ft}$ from Ground Zero. See Fig. A.5 for drawing. Figure 9 shows the closed shaft entrance to the covered trench before the blast. This shelter suffered no damage. No cracks were noted in the concrete roof slab. There was no permanent deflection of the roof slab.

(f) Block-wall Basement Exit at 1800 Ft from Ground Zero. See Fig. A.6 for plan. Figure 10 is a view of the entrance to the block-wall basement exit before the blast. Figure 11 shows the minor damage done to the exterior of this shelter by the blast. There was no interior damage. The roof slab showed no evidence of any cracking.

(g) Concrete-pipe Shelter with Closed Shaft Entrance at 1800 Ft from Ground Zero. For construction drawing of this shelter see Fig. A.7. Figure 12 shows the shaft entrance to the concrete-pipe shelter before the blast. The blast caused no damage to this shelter. A careful examination of the entire pipe interior disclosed no cracks. 
(h) Covered Trench Shelter at 3500 Ft from Ground Zero. This is the same type shelter that was constructed at $1800 \mathrm{ft}$ from Ground Zero. Figure 13 shows the entrance to the shelter before the blast.

An unweighted, dressed male mannequin of $37 \mathrm{lb}$ was placed in this shelter and its position marked on the bench and roof slab. No movement of or damage to the mannequin by blast was noticeable. The shelter was undamaged. The roof slab was uncracked.

(i) Wooden Lean-to Shelter at 3500 and 7500 Ft from Ground Zero. See Fig. A.8 for the construction drawing. This shelter was built $6 \mathrm{ft} 0$ in. long instead of the $8 \mathrm{ft} 0 \mathrm{in}$. shown. Figures 14 and 15 show the wooden lean-to in the basement of the house at $3500 \mathrm{ft}$ before and after the blast. The mannequin in the shelter was removed after the explosion and before the photograph was taken.

Figure 16 shows the wooden lean-to shelter in the basement of the house at $7500 \mathrm{ft}$ before the blast. The clothed female dummies weighed $30 \mathrm{lb}$ each, and the child weighed $7 \mathrm{lb}$. All mannequins were undamaged and remained in their original positions.

No damage was caused to either shelter by the blast.

(j) Basement Corner Room Shelter at 3500 and 7500 Ft from Ground Zero. For drawing of this shelter see Fig. A.9. Figure 17 is a view of the interior of this shelter in the house at $3500 \mathrm{ft}$ before the blast. Figures 18 and 19 show the interior of this shelter at $7500 \mathrm{ft}$ before and after the blast. Male mannequins weighed $35 \mathrm{lb}$; females, $30 \mathrm{lb}$; and the child, $7 \mathrm{lb}$. None of these mannequins were damaged or moved by the blast.

Figure 20 illustrates the minor damage in the basement corner room at $3500 \mathrm{ft}$ after the blast. Only one roof joist cracked under the debris load of the collapsed house above.

The basement corner room at $7500 \mathrm{ft}$ was not damaged.

\section{DISCUSSION}

\subsection{Analysis of Gamma-radiation Data}

Badges were placed in all shelters to measure initial gamma radiation. Very little penetration was expected because of the relatively large mass of earth between the explosion and the interiors of the shelters resulting from the low incident angle caused by the $300-\mathrm{ft}$ burst. Recovery of the badges was expected within $2 \mathrm{hr}$ after the detonation. A severe fall-out in the area covered the shelters and houses and delayed postoperation plans. The badges in the basement shelters at $7500 \mathrm{ft}$ were recovered $7 \mathrm{hr}$ after the blast and most of the others $30 \mathrm{hr}$ after. A few were collected as late as $78 \mathrm{hr}$ after the explosion.

High residual radiation levels remained in the area for two days. Monitor reports showed wide fluctuations in readings, probably due to the shifting of the sand and dust under the action of the wind. Under these conditions it was impossible to differentiate between the amounts of initial and residual radiation to which the badges had been exposed.

\subsection{Analysis of Thermal-radiation-effects Data}

The paper temperature-recording strips in the shelters at 1230,1450 , and $1800 \mathrm{ft}$ did not show discoloration. This would indicate that if there was any rise in temperature it did not increase sufficiently to reach $52^{\circ} \mathrm{C}$ or $94^{\circ} \mathrm{F}$, the lowest temperature which the strips were designed to record.

Since there was no melting of the nylon swatches or paraffin cubes, the amount of thermal energy entering the shelters even at close ranges must have been small, probably not sufficient to cause even slight skin burns.

\subsection{Analysis of Blast-effects Data}

The pressure inside the reinforced concrete basement exit type shelter at $1230 \mathrm{ft}$ was sufficient to break the bench. The actual pressure acting on the bench and mannequin is unknown. About $75 \%$ of the weight of the mannequin was located below the waist. It seems possi- 
ble that the blast wave entering the shelter through the entrance may have exerted sufficient force between the wall of the shelter and the back of the mannequin to accelerate the light upper half forward, breaking the dowel pin connecting the two parts and twisting the upper part to its after-blast position. From the after-blast position of the lower part of the mannequin, it can be assumed that the dropping of the entrance end of the bench plus the force exerted in breaking the upper part loose were the causes of its displacement. The damage to the mannequin indicated that pressure inside this shelter should be studied.

The mannequins in the shelters at 1450 and $1800 \mathrm{ft}$ did not move; yet the test pressure at the 1450 -ft shelter was only $35 \%$ less than that at the reinforced concrete basement exit shelter. The entrances of the 1230- and 1450-ft shelters, however, had different orientations (see Fig. A.1), and this may have had some effect on the admission of pressure.

The concrete roof slabs of the underground shelters were designed to resist a dynamic load, with the maximum midspan deflection limited to about $1 / 30$ of the span. With this deflection, cracking of the slab was to be expected since the reinforcing steel was allowed to yield. However, no cracks were visible. Deflections must have been in the elastic range since no permanent deflections were observed.

At first it was believed that the design assumptions were in error: (1) that the mass of the earth cover acted with the slab, (2) that there was no attenuation of pressure on the roof slab through the soil, and (3) that pressure on the underside of the slab was zero. Later, when the actual pressures on the shelters were found to be much lower than anticipated, the behavior of the slabs was understandable. Under the test pressures listed below the slabs acted elastically.

Shelter Distance to $\mathrm{GZ}$, ft Design pressure, psi Test pressure, psi

$\begin{array}{llll}\text { R.C. basement exit } & 1230 & 50 & 23 \\ \text { Covered trench } & 1450 & 23 & 15 \\ \text { Covered trench } & 1800 & 23 & 10\end{array}$

No conclusions relative to the adequacy of the wood-covered trench should be drawn from the failure of the wall. If the proper number of anchor bolts had been used to anchor the plates to the walls, it is believed that the tops of the walls would have been sufficiently braced to cause the walls to span the distances between the roof and floor without failure.

The debris load on the basement shelters at $3500 \mathrm{ft}$ was small; so these shelters were not tested to their maximum capacity, such as might be experienced in the collapse of a masonry house.

\subsection{Conclusions}

Thermal energy entering the shelters probably would not have caused skin burns to human occupants.

There is some evidence that pressure inside the shelters may cause injury to occupants and that their safety may depend upon the orientation of the entrances.

Although the adequacy of the shelters at full design pressures could not be determined, since the actual test pressures were about one-half the design value, the test nevertheless showed that the designs are structurally satisfactory at the pressures received. Since in any atomic attack the majority of residences in the attack area - and consequently the home type shelters - would not be in the regions of high pressure, the information obtained was of value to Civil Defense.

\subsection{Recommendations}

Future tests should be made to subject the reinforced concrete basement exit shelter and the covered trench shelter to blast pressures of about 45 and 25 psi, respectively. 
The wood-covered trench, built according to plan, should be tested again at a blast pressure of about 25 psi.

Both types of indoor shelters should be tested under the debris load of a masonry house.

All future tests of shelters should include instrumentation to measure interior temperatures and blast pressures.

Future tests should include devices for reducing or keeping out the blast pressures.

\section{REFERENCE}

1. Archie P. Flynn, FCDA Family Shelter Evaluation, Buster Project 9.1a Report, WT-359, 1952. 


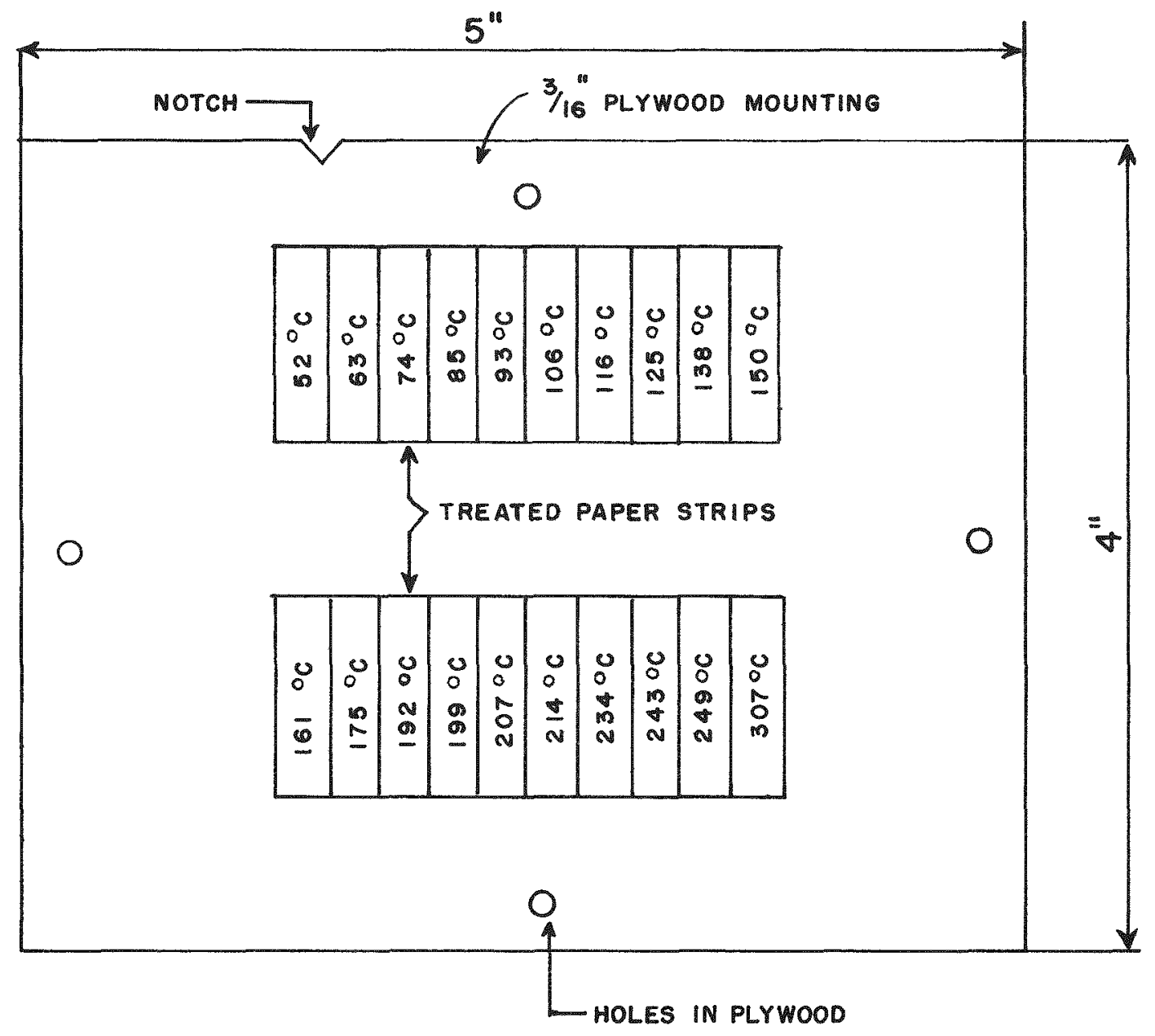

Fig. 1-Temperature-recording strips. 


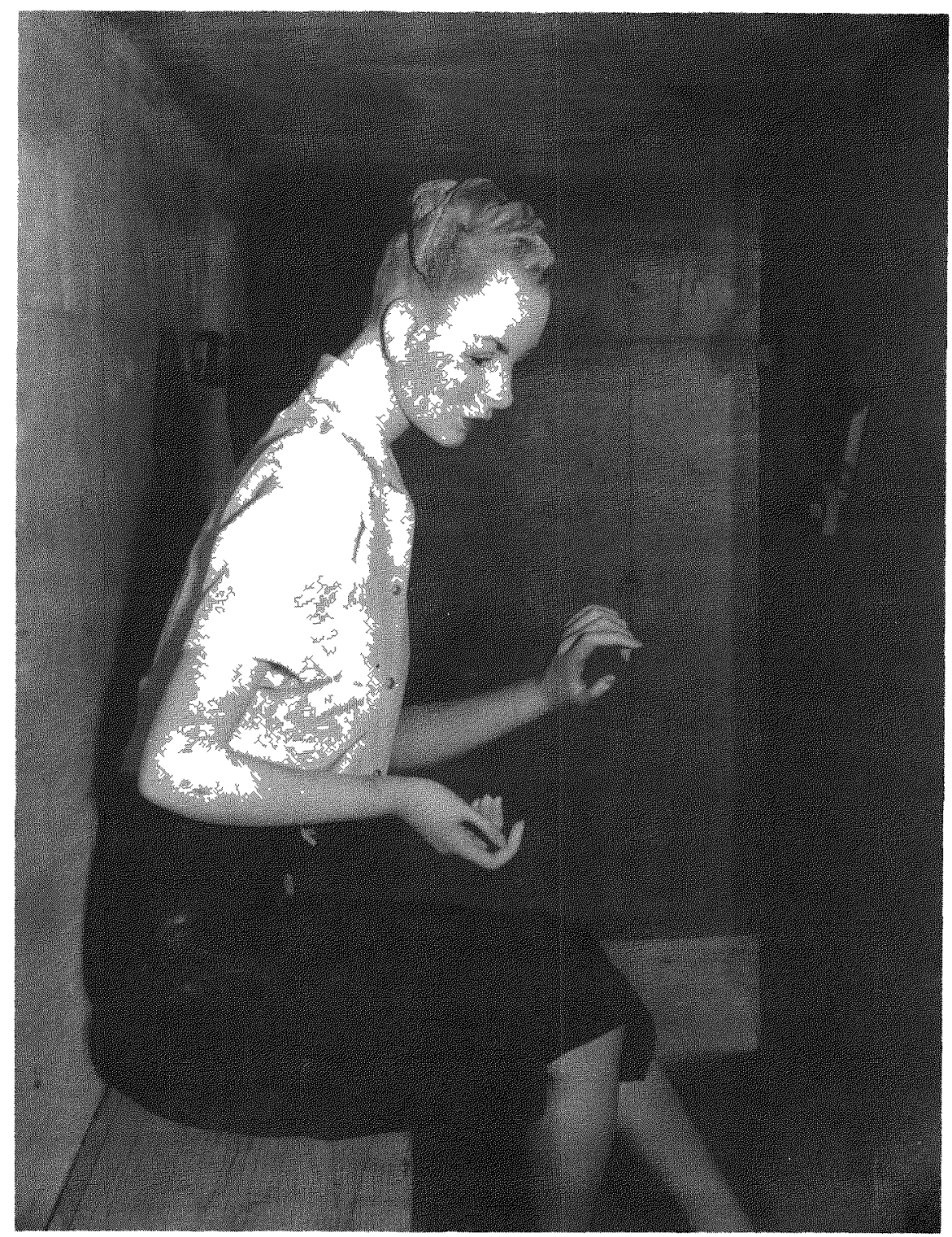

F1g. 2-Reinforced concrete basement exit before blast. 


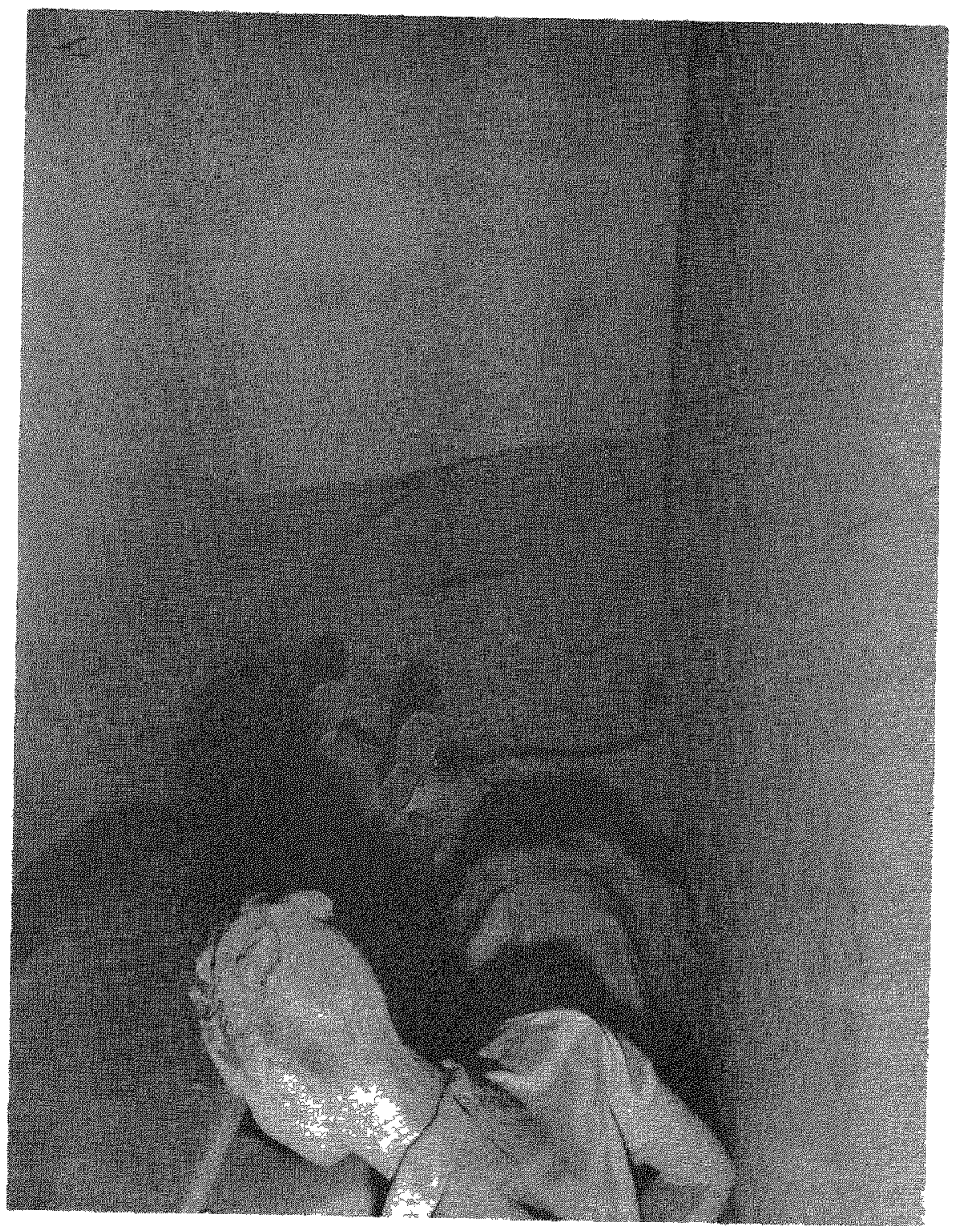

Fig. 3-Reinforced concrete basement exit after blast. 


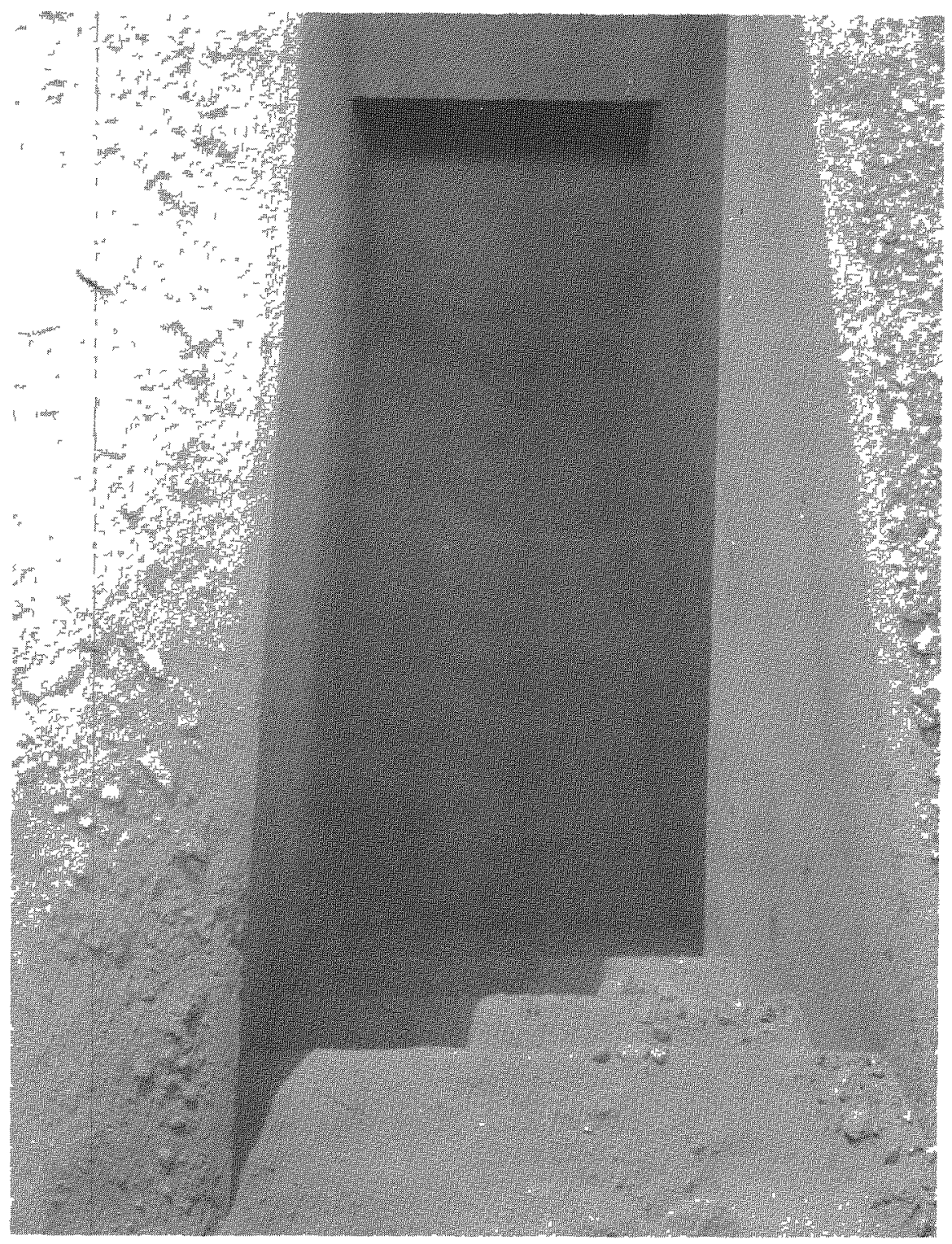

Fig. 4- Entrance to reinforced concrete basement exit after blast. 


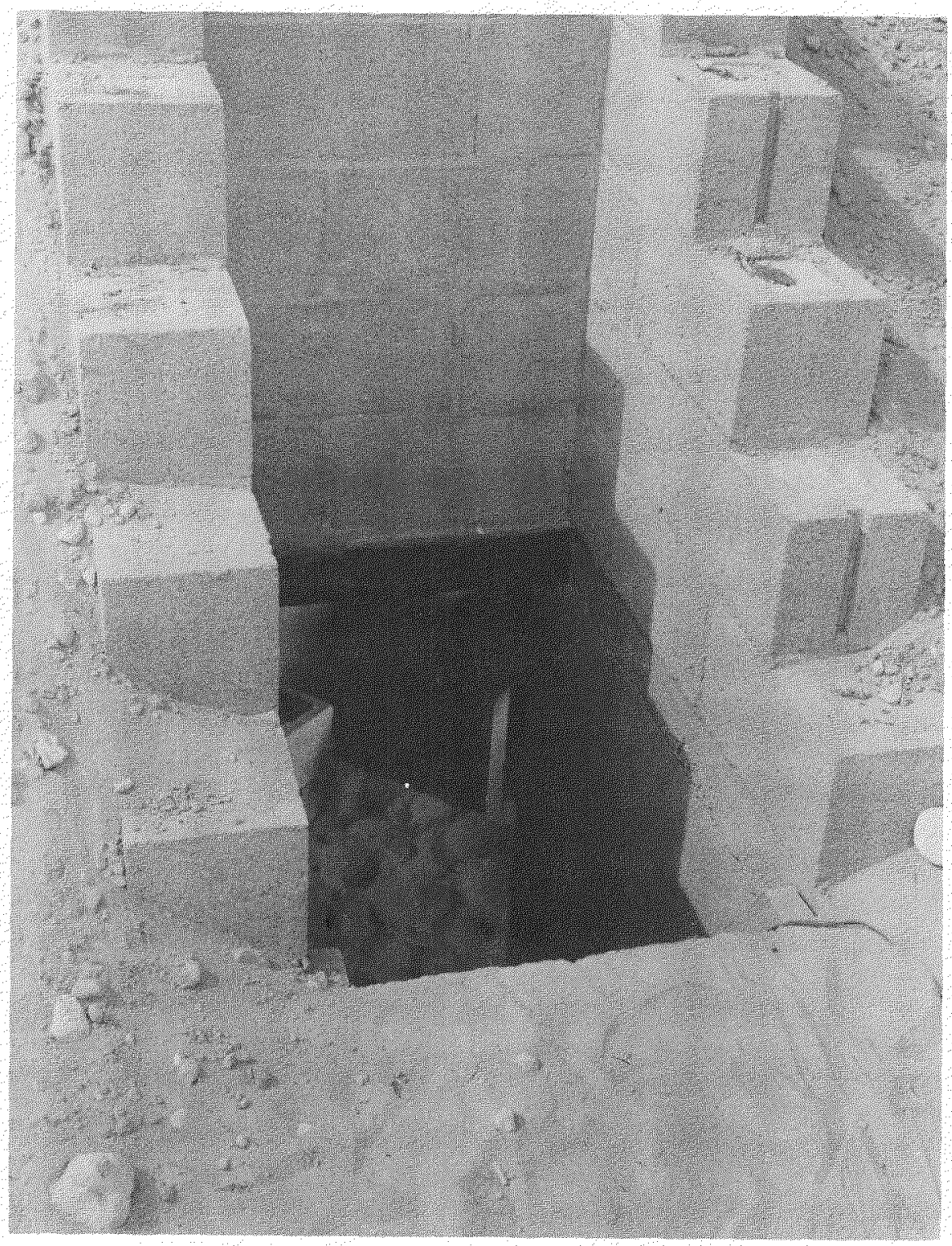

Fig. 5-Entrance to covered trench at $1800 \mathrm{ft}$ before blast. 


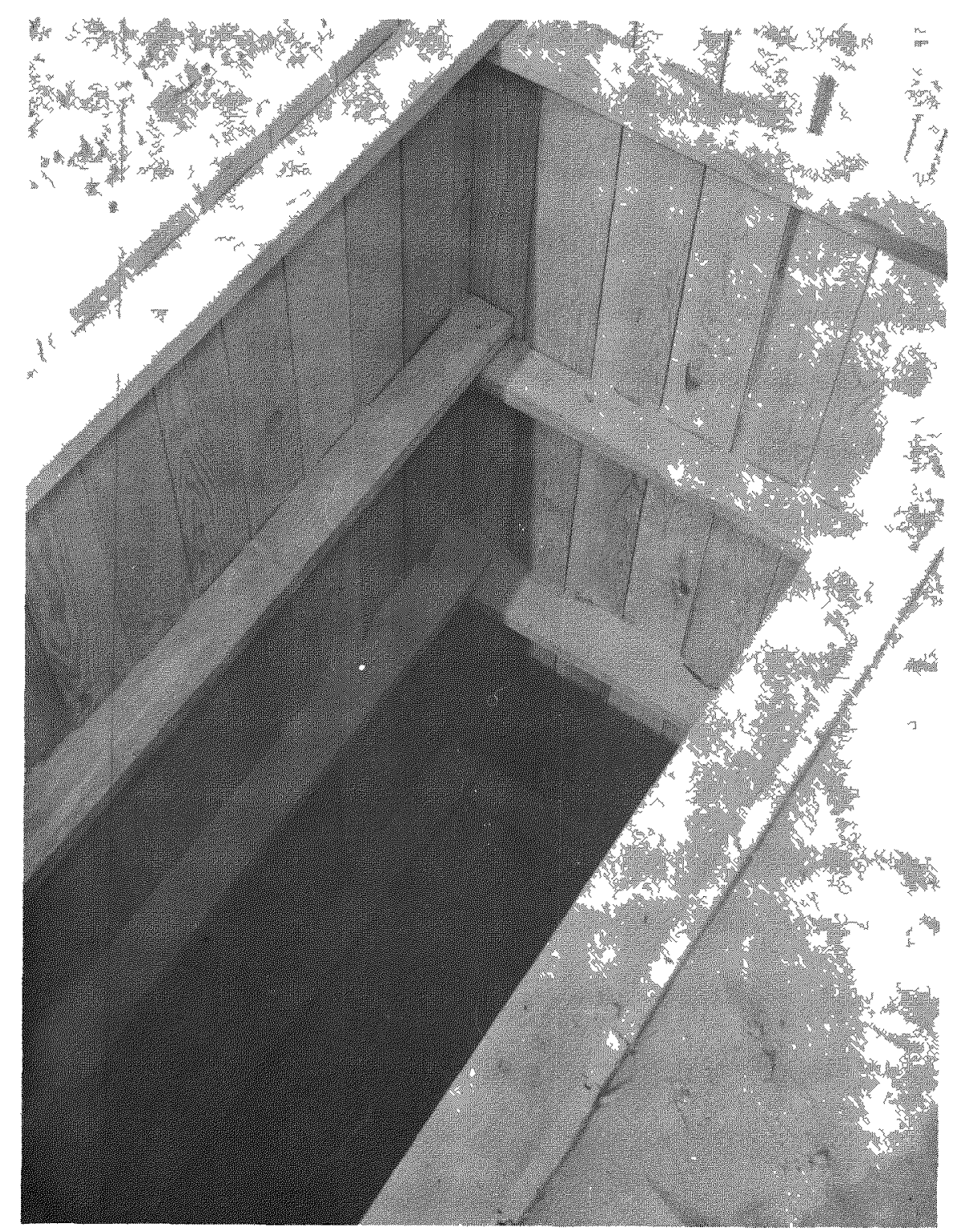

Fig. 6-Shaft entrance to wood-covered trench before blast. 


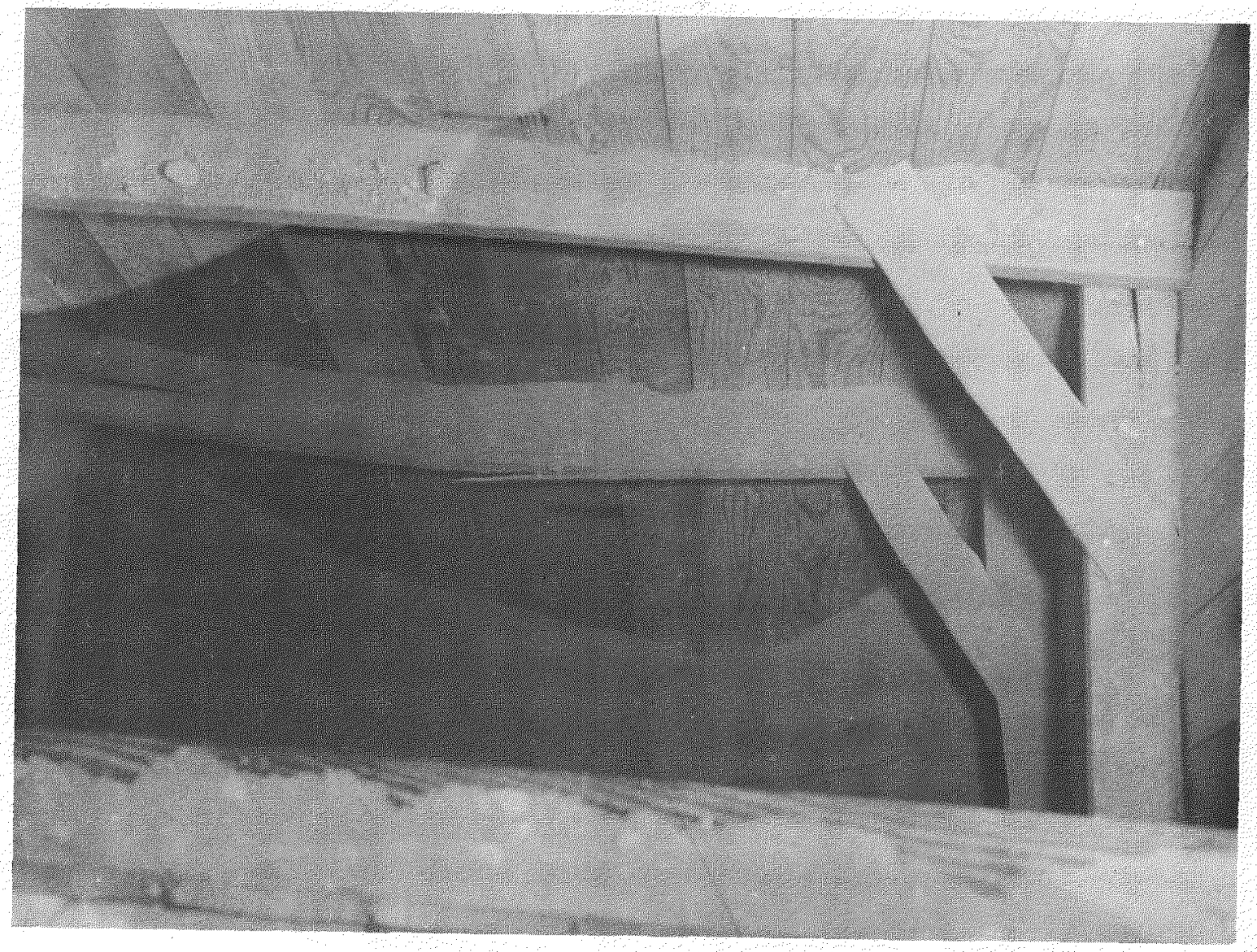

Fig. 7-Shafr entrance to wood-covered trench after blast. 


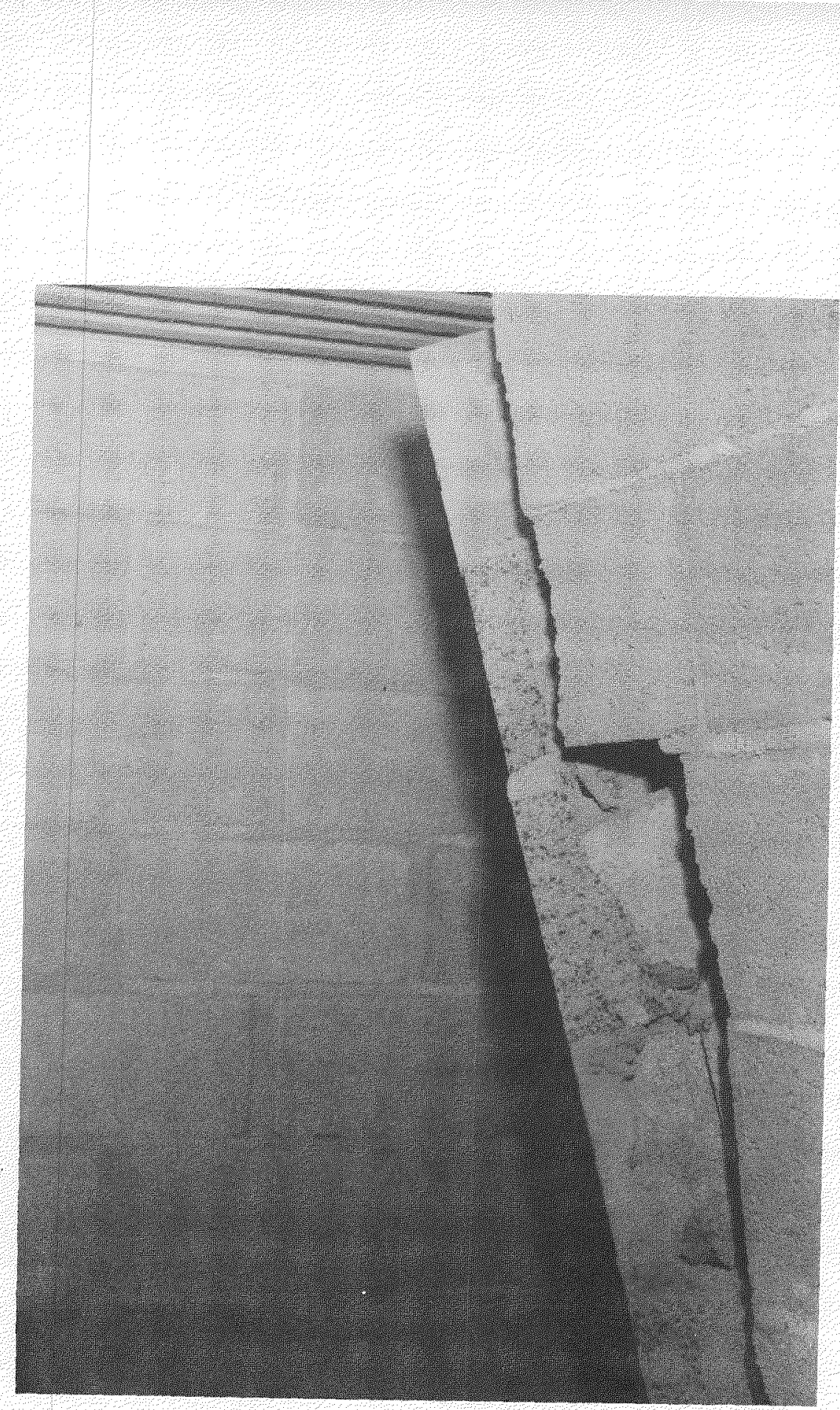

Fíg. 8-Blast damage to wood-covered trench. 


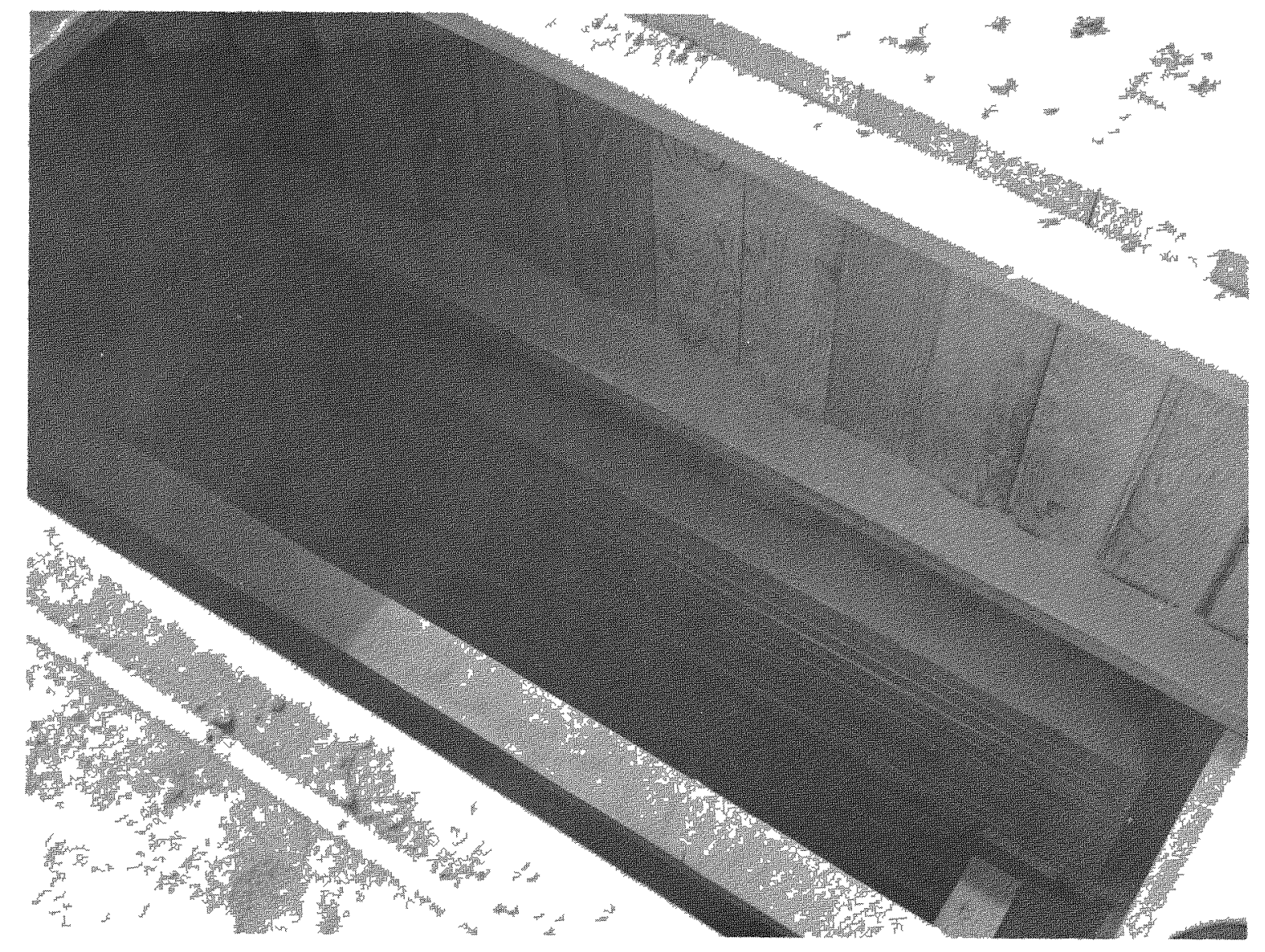

Fig. 9-Closed entrance to covered trench before blast. 


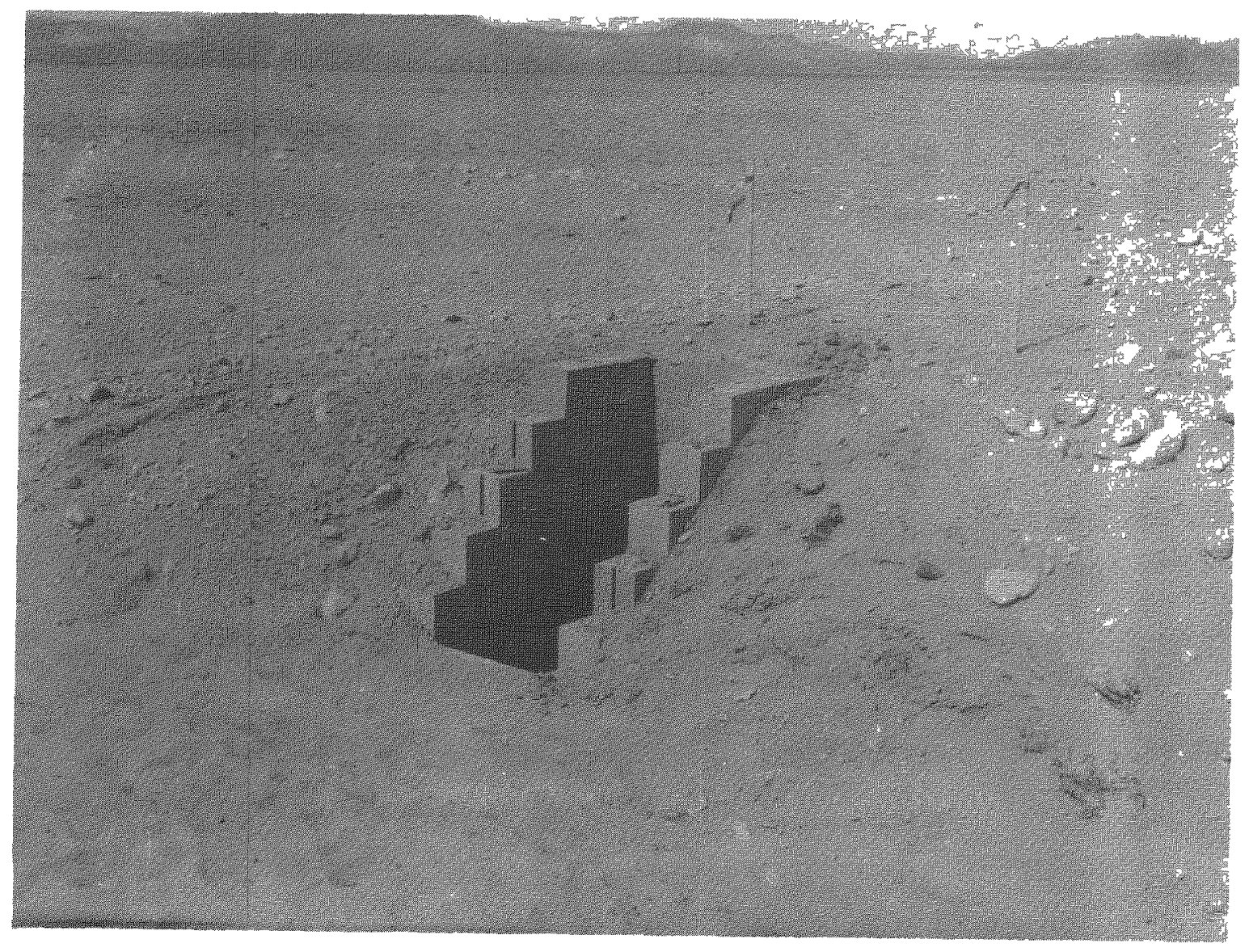

Fig. 10-Entrance to block-wall basement exit before blast. 


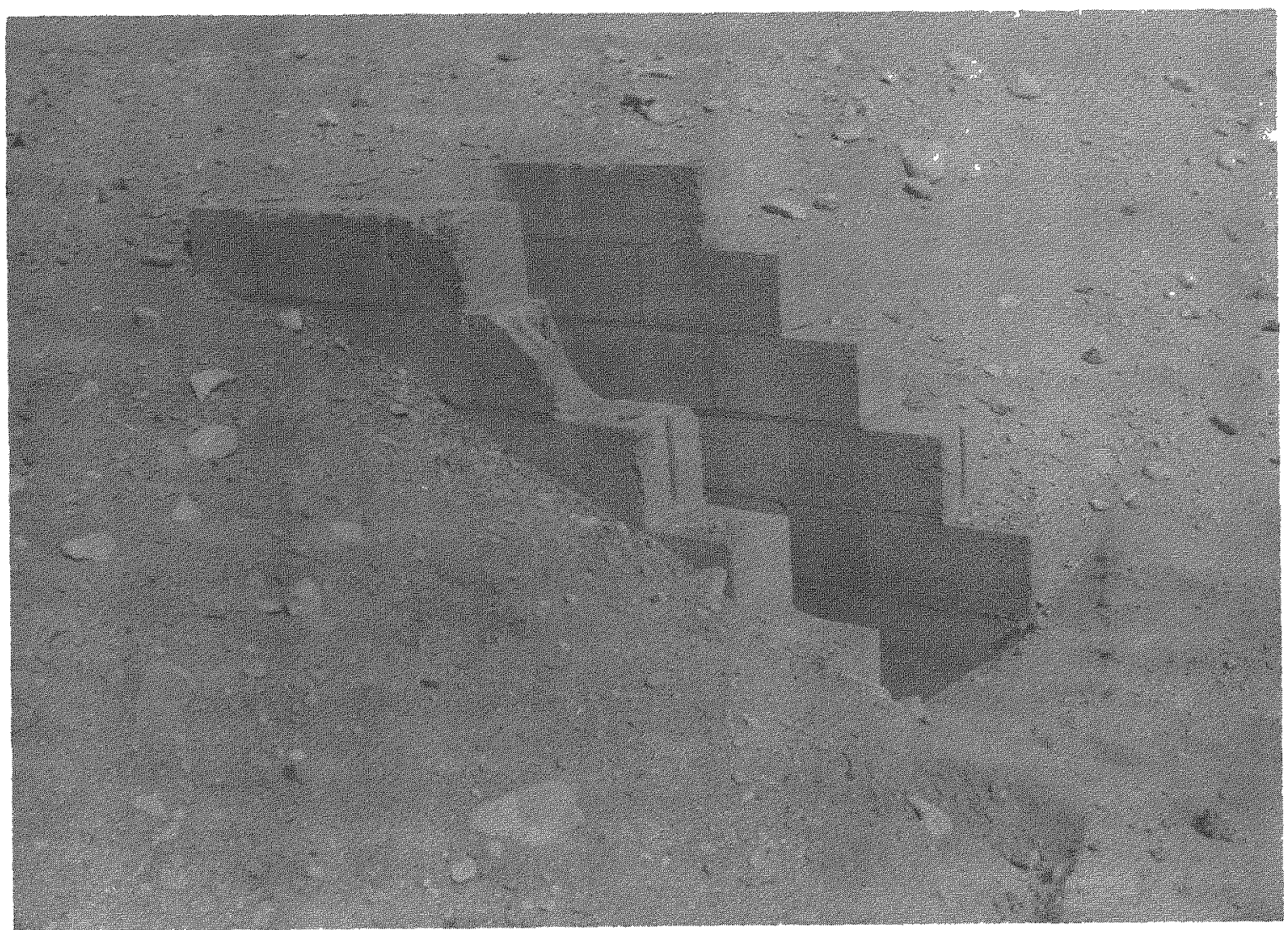

Fig. 11-Entrance to block-wall basement exit after blast. 


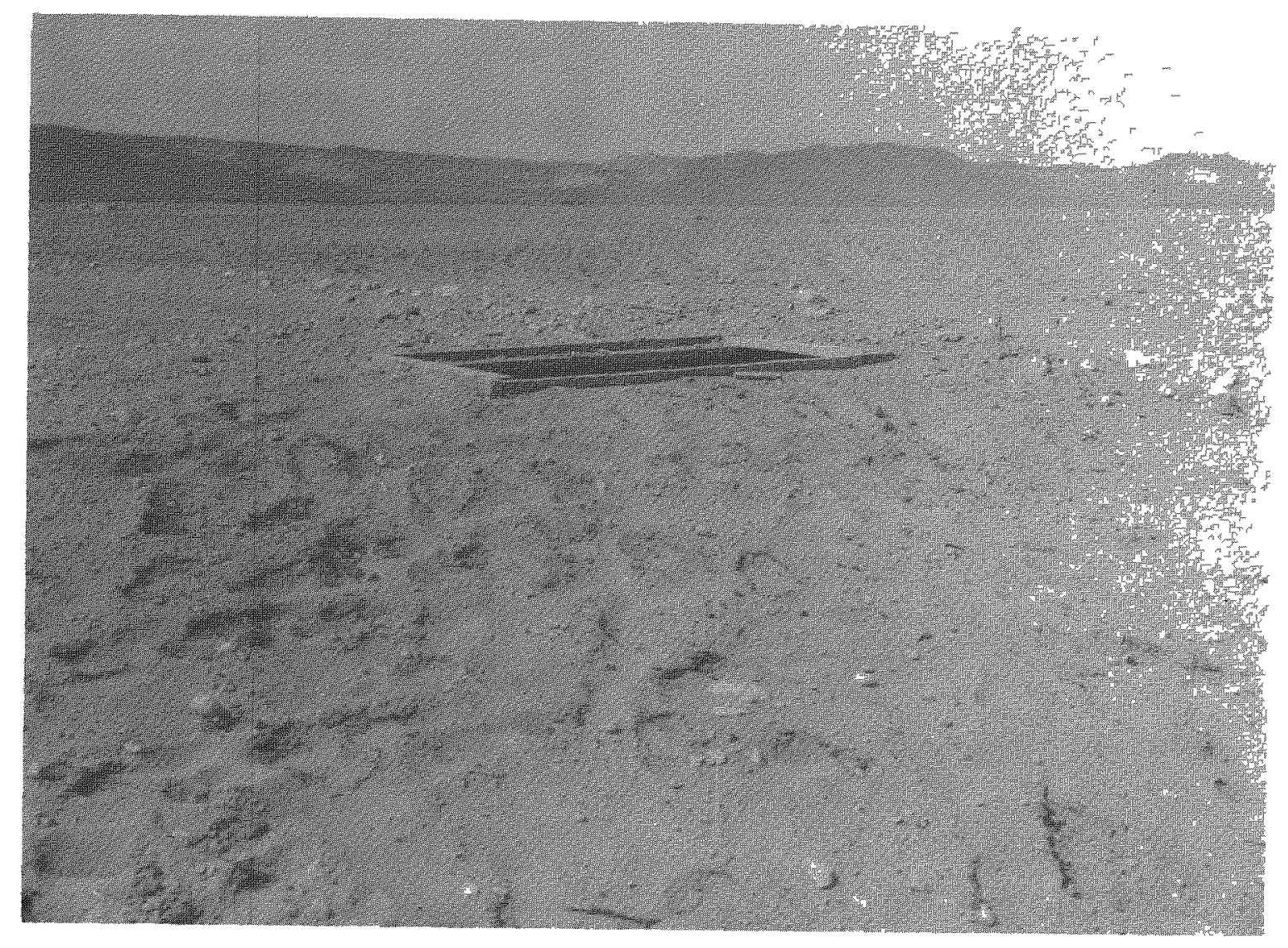

Fig. 12-Shaft entrance to concrete pipe before blast. 


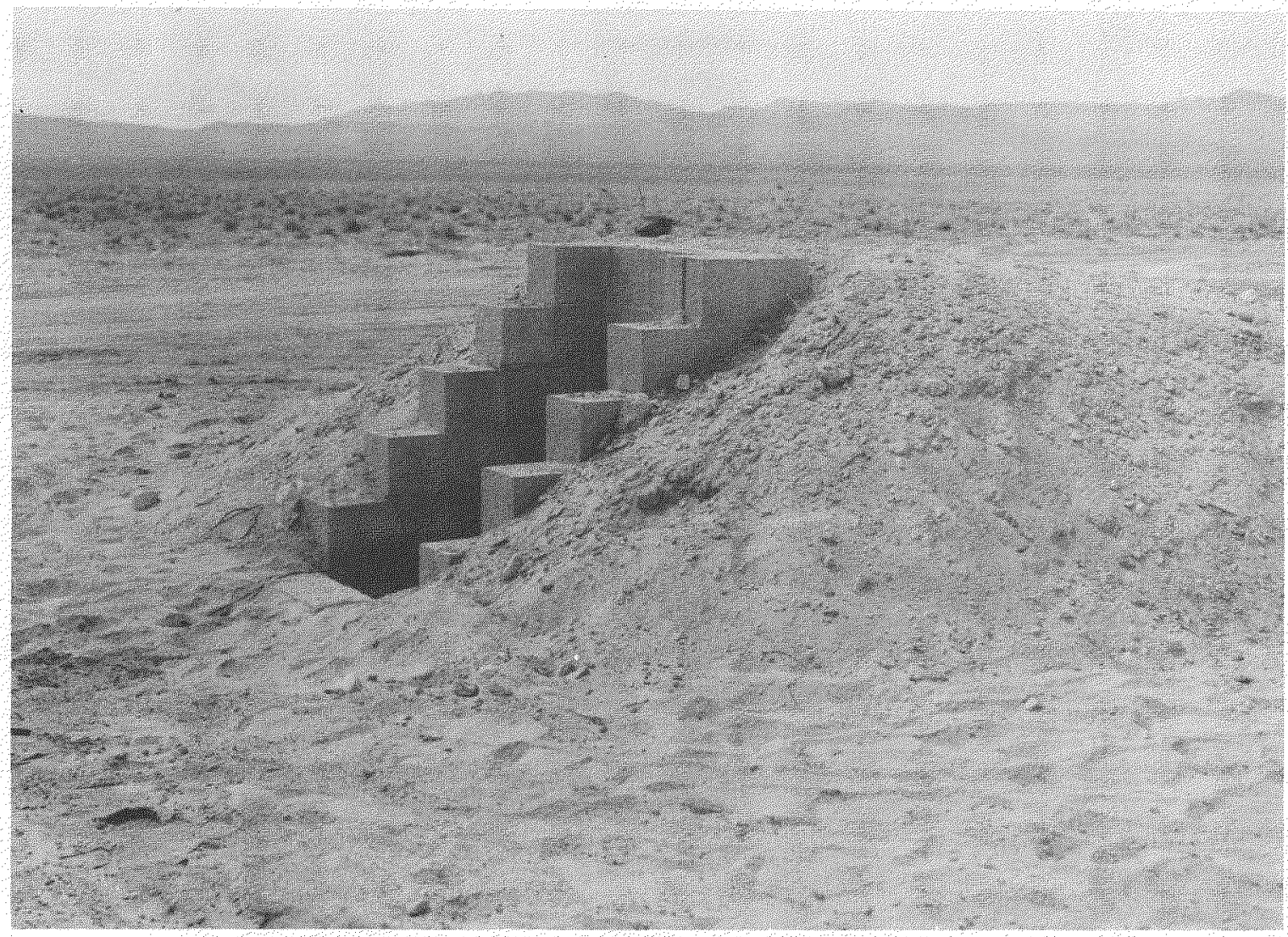

Fig. 13-Covered trench at 3500 ft before blast. 


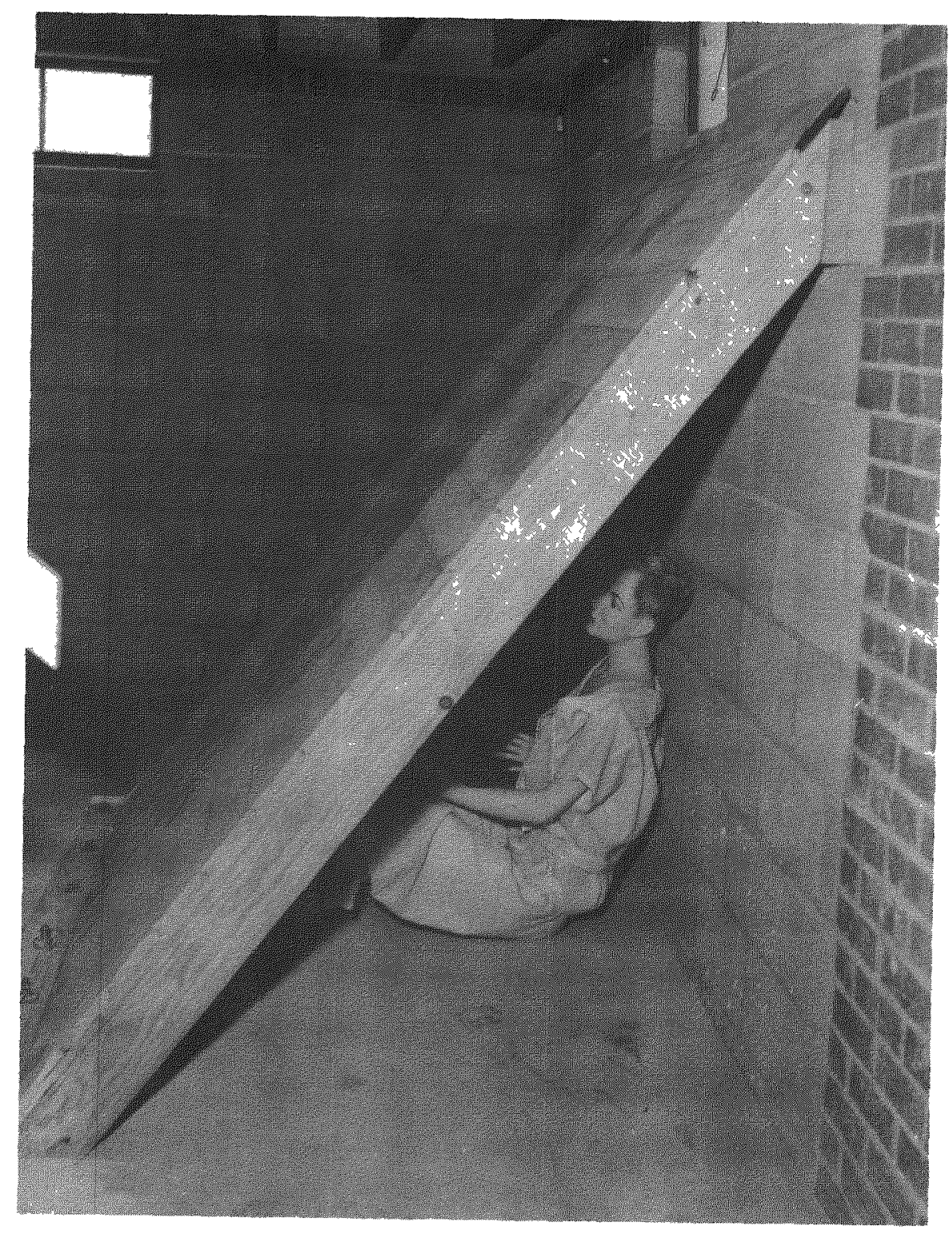

Fig. 14- Lean-to at $3500 \mathrm{ft}$ before blast. 


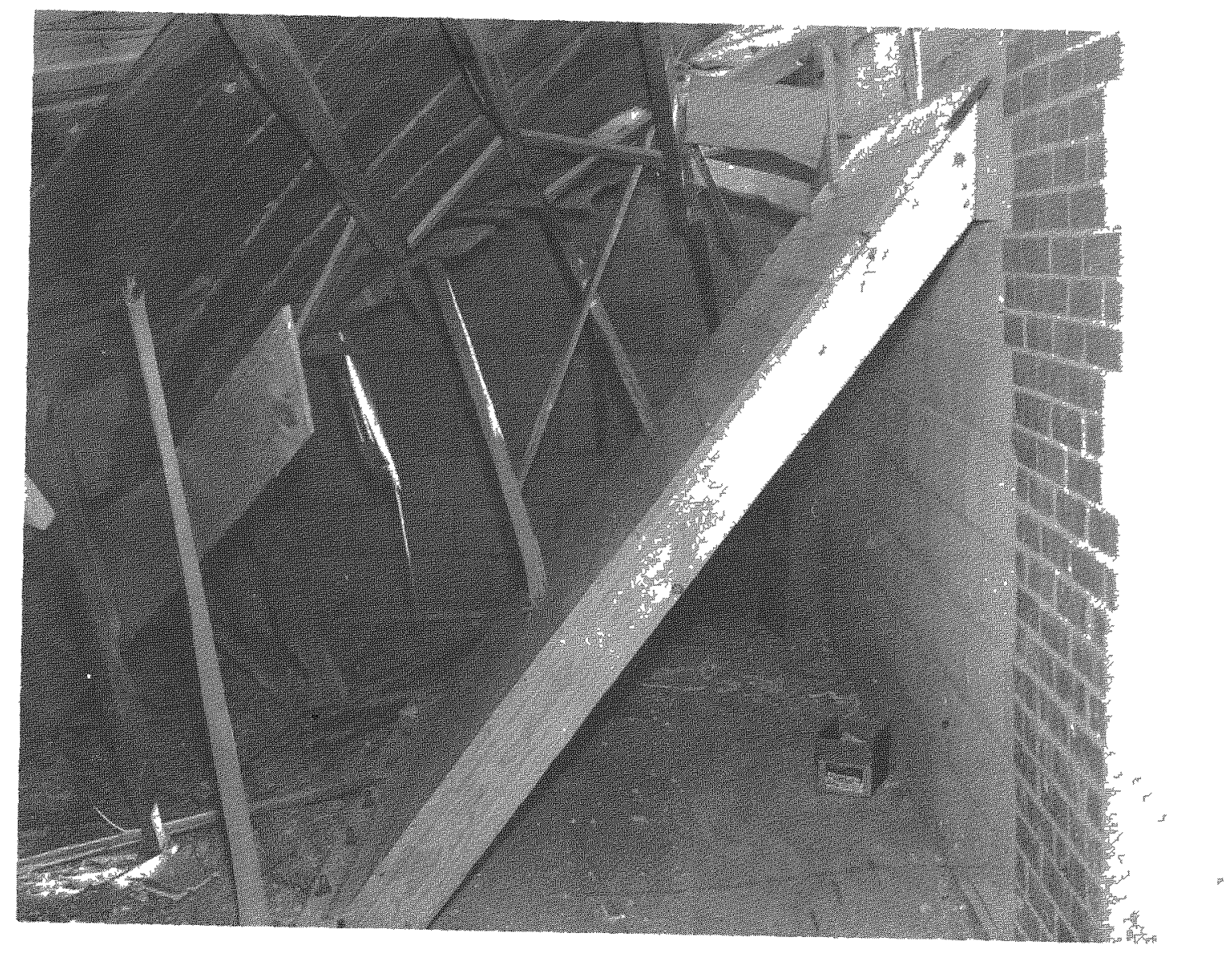

Fig. 15-Lean-to at $3500 \mathrm{ft}$ after blast. 


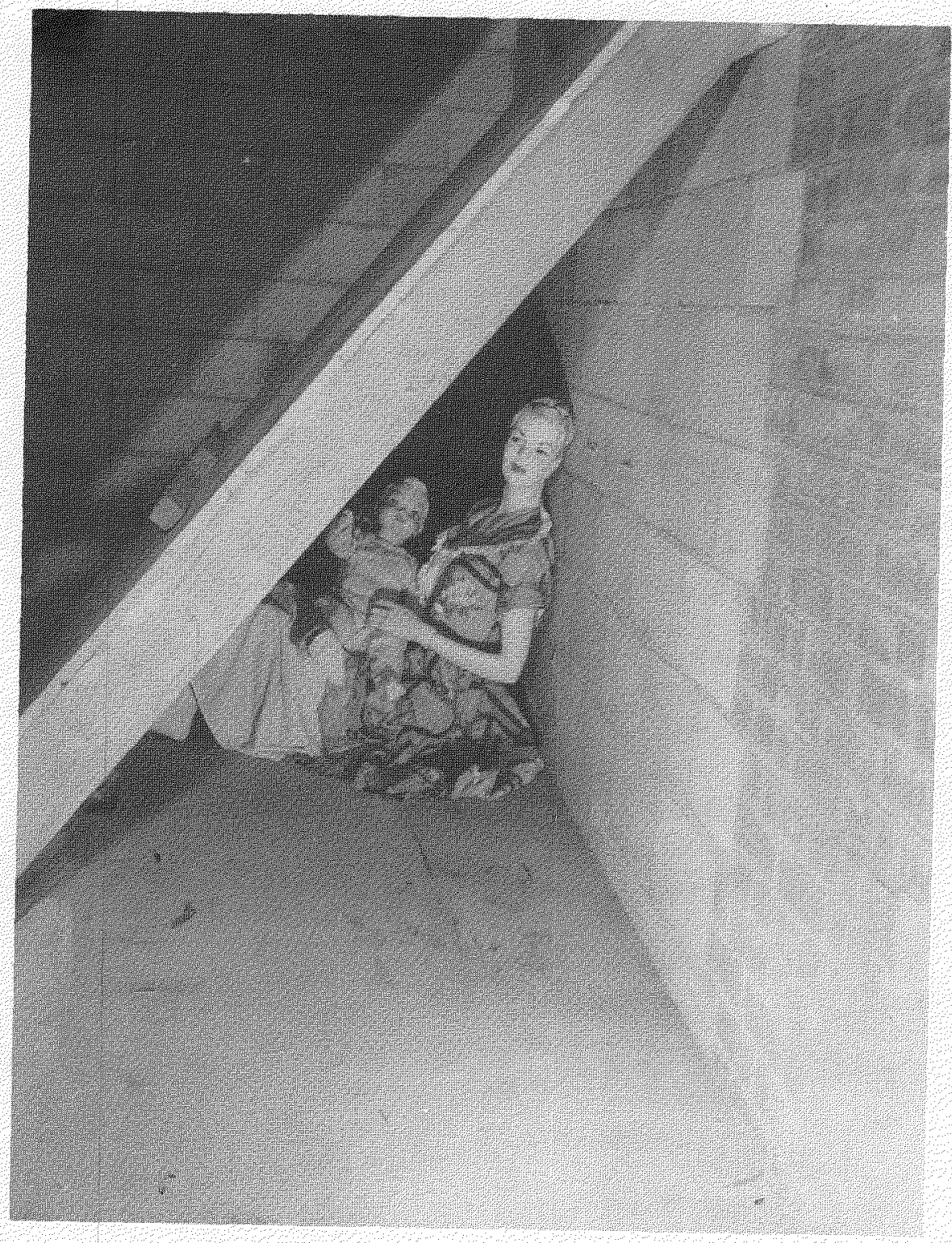

Fig. 16 - Lean-to at $7500 \mathrm{ft}$ before blast. 


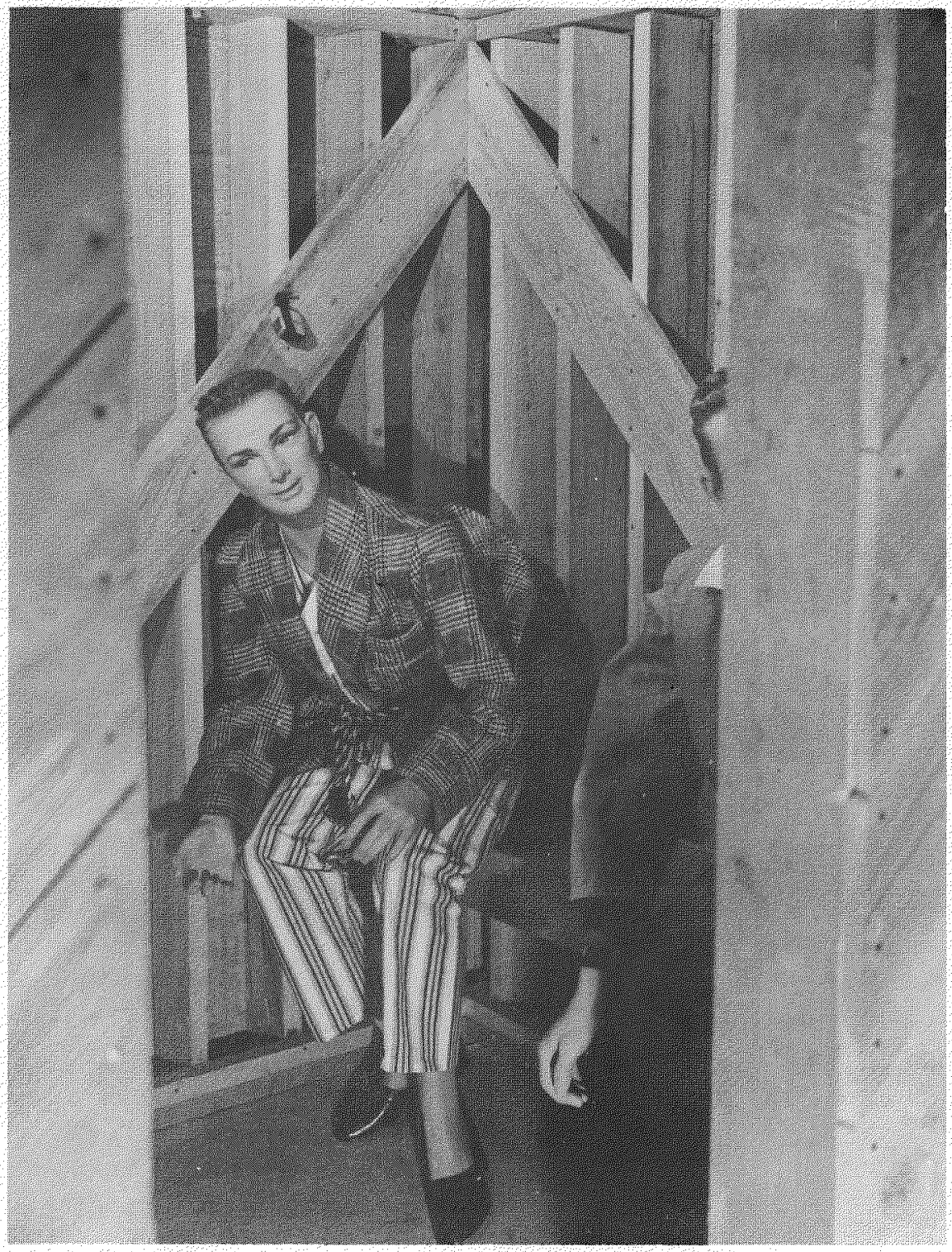

Fig. 17-Basement comer room at $3500 \mathrm{ft}$ before blast. 


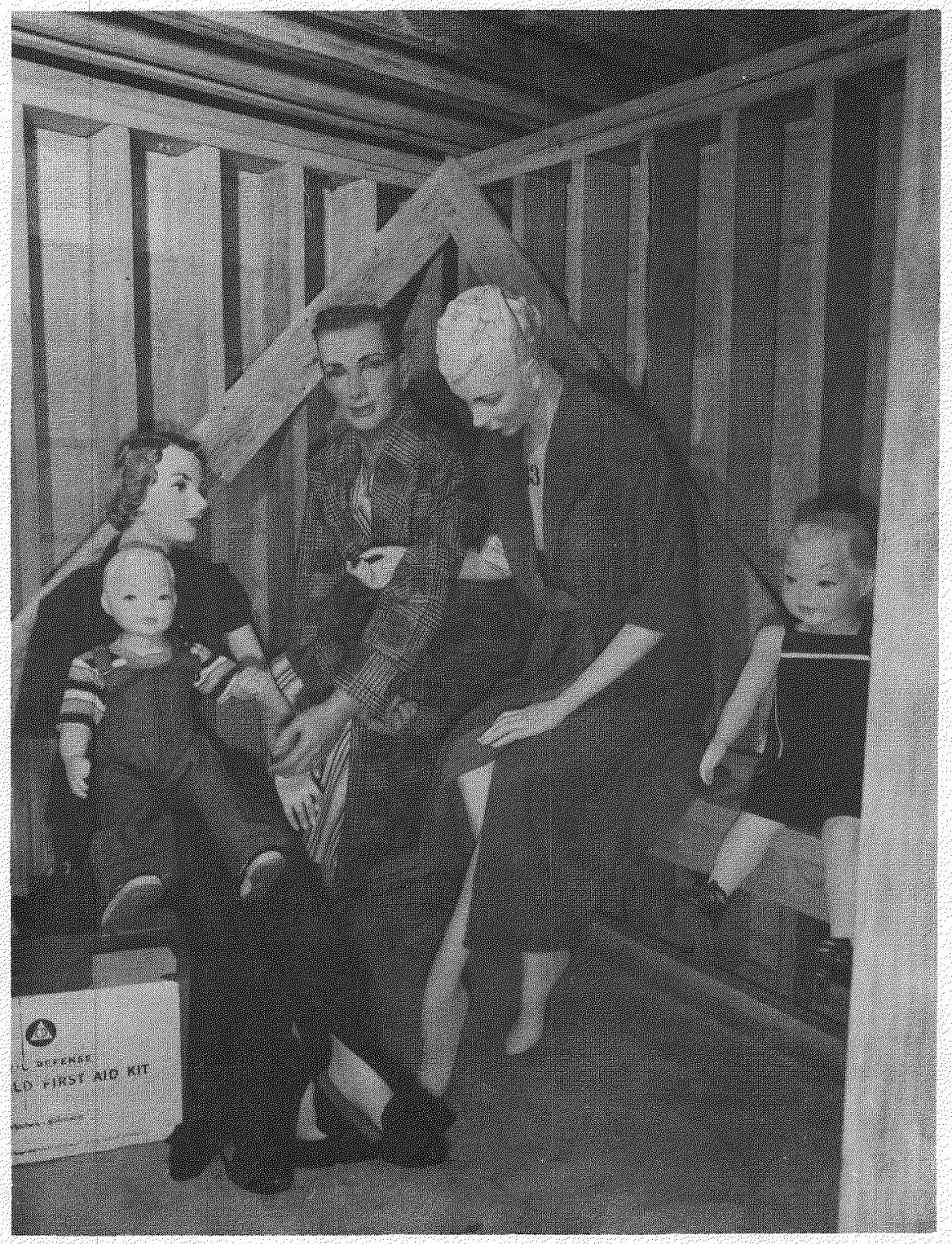

Fig. 18-Basement corner room at $7500 \mathrm{ft}$ before blast.

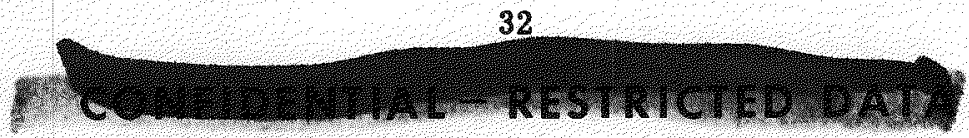




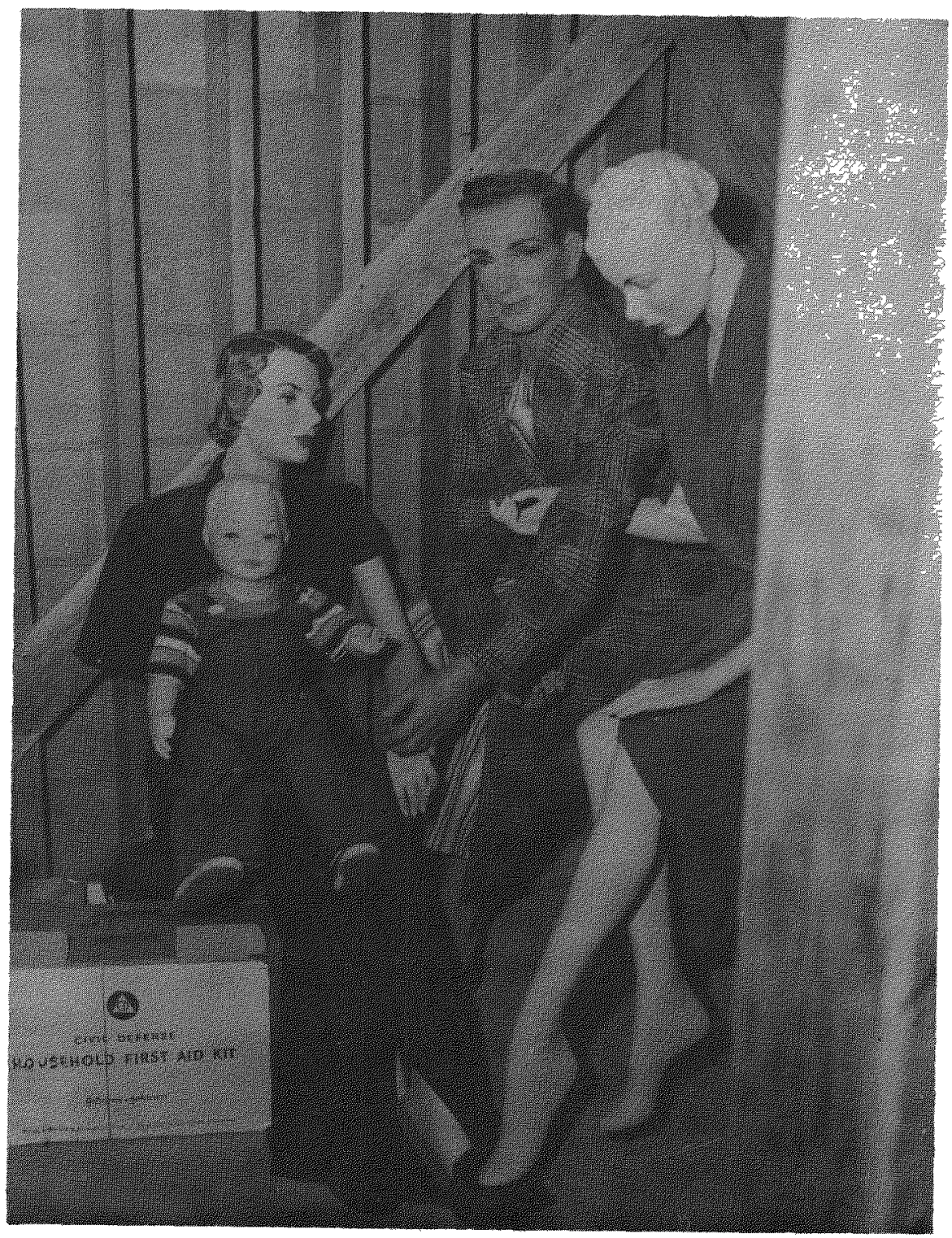

Fig. 19-Basement coner room at $7500 \mathrm{ft}$ after blast. 


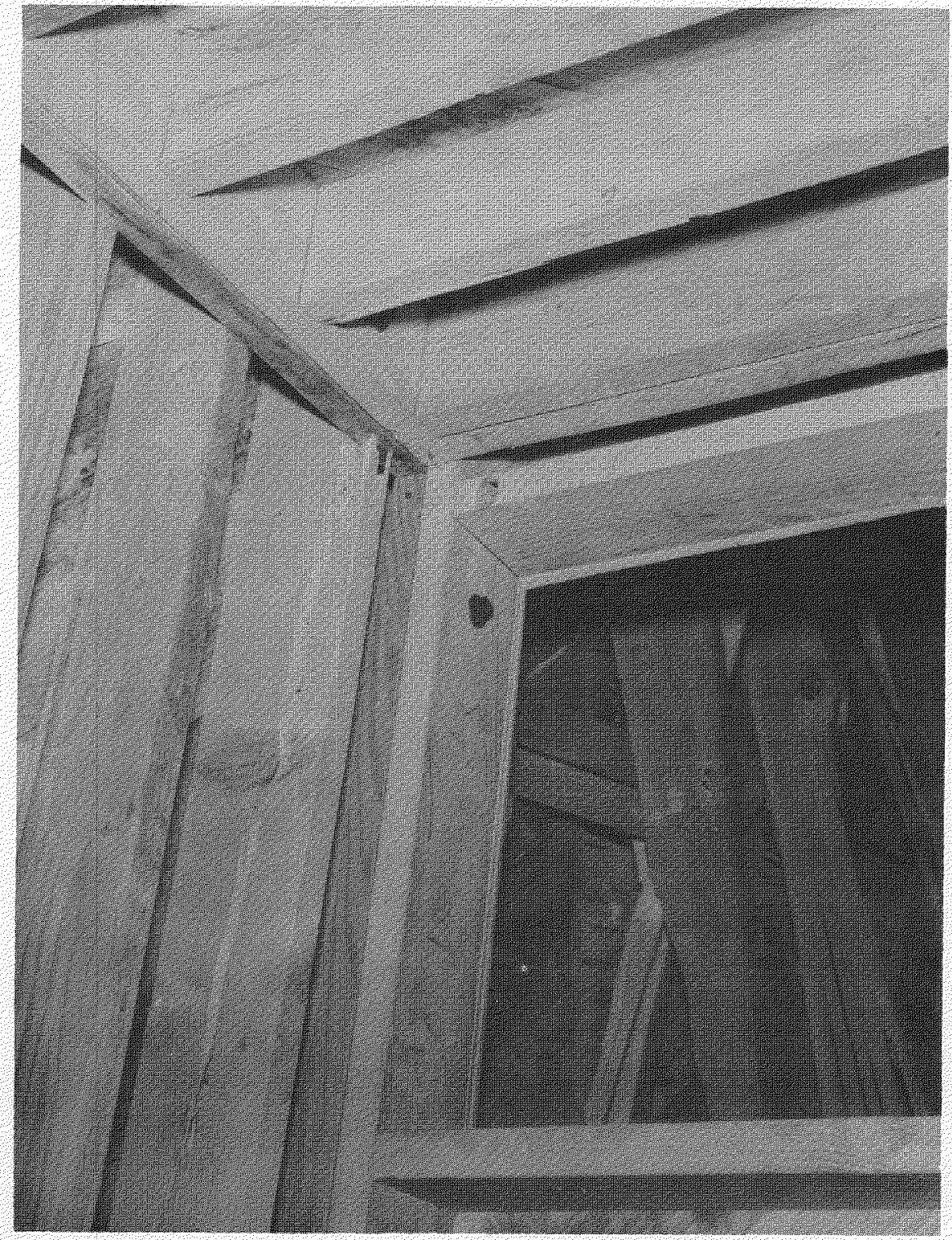

Fig. 20 - Damage to basement corner room at $3500 \mathrm{ft}$. 
APPENDIX

LOCATIONS AND STRUCTURAL DETAILS OF SHELTERS 
•

.

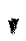

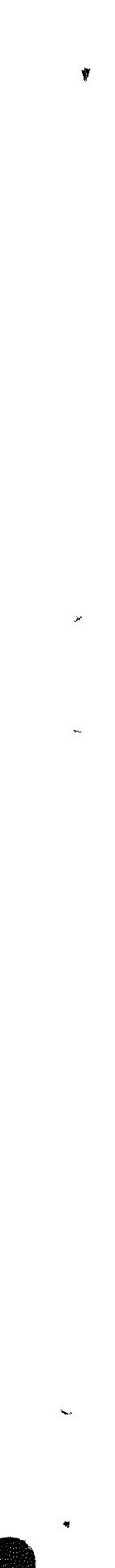

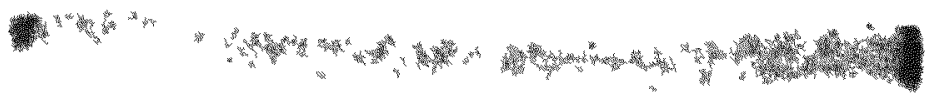




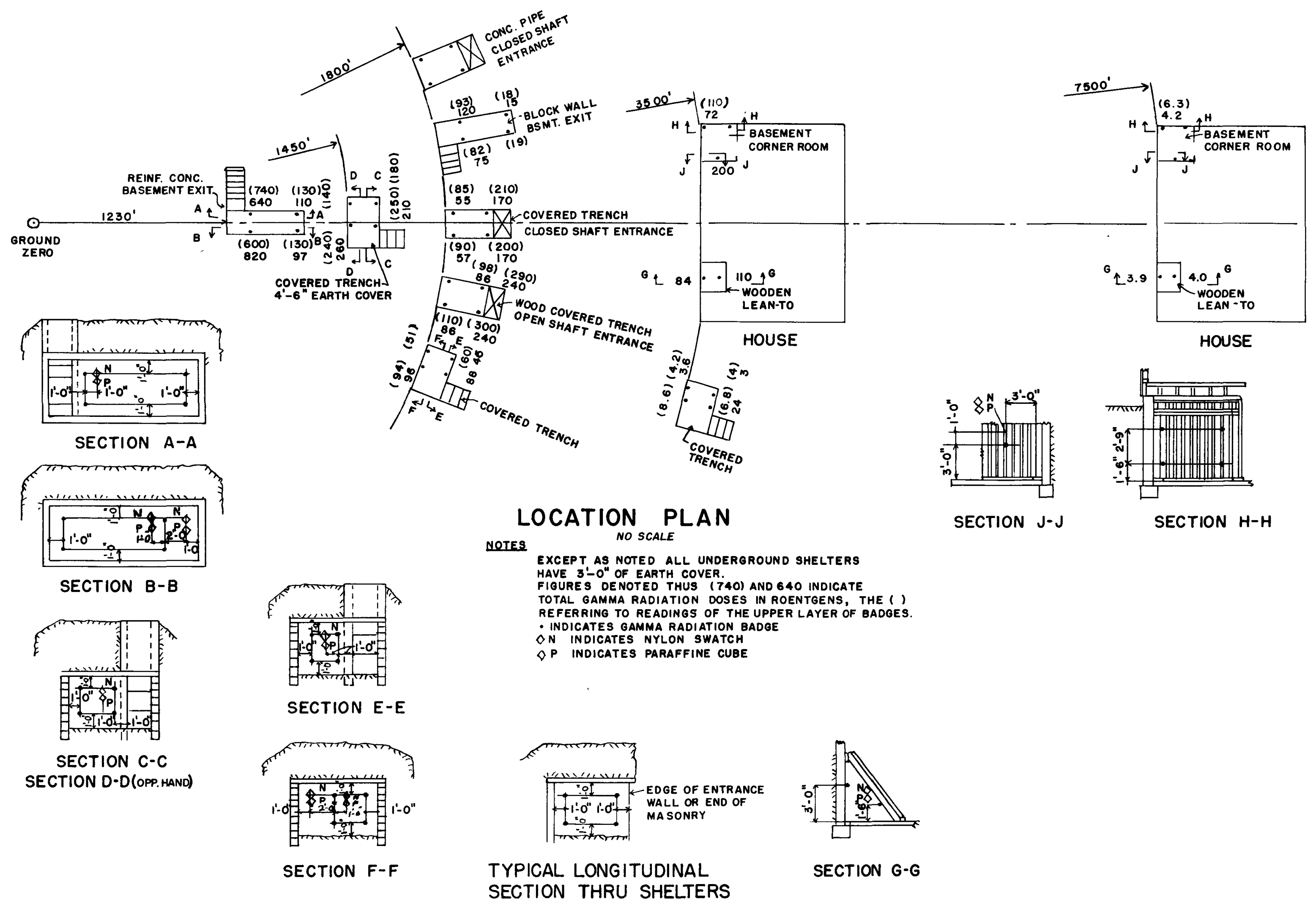

Fig. A.1-Location plan. 


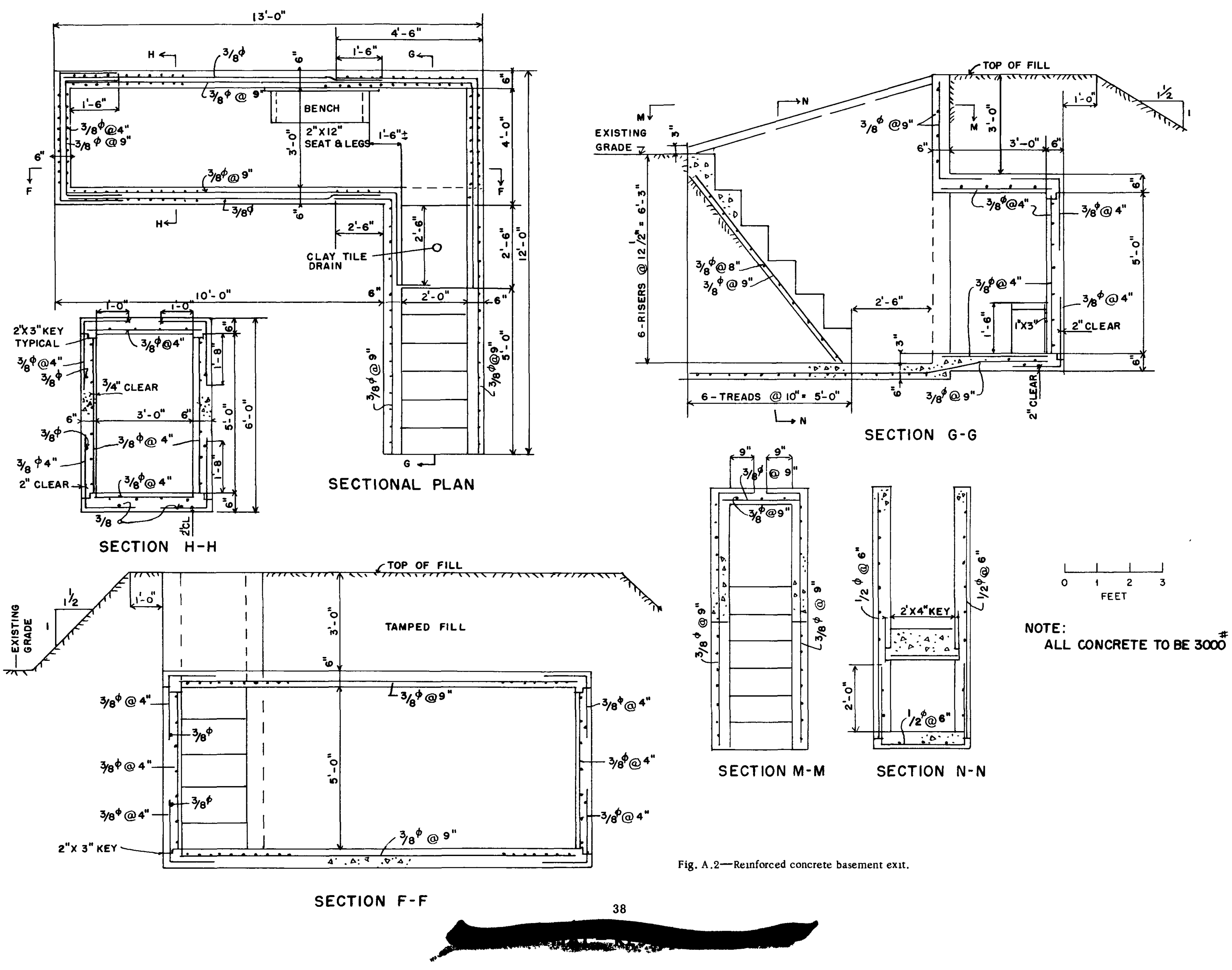




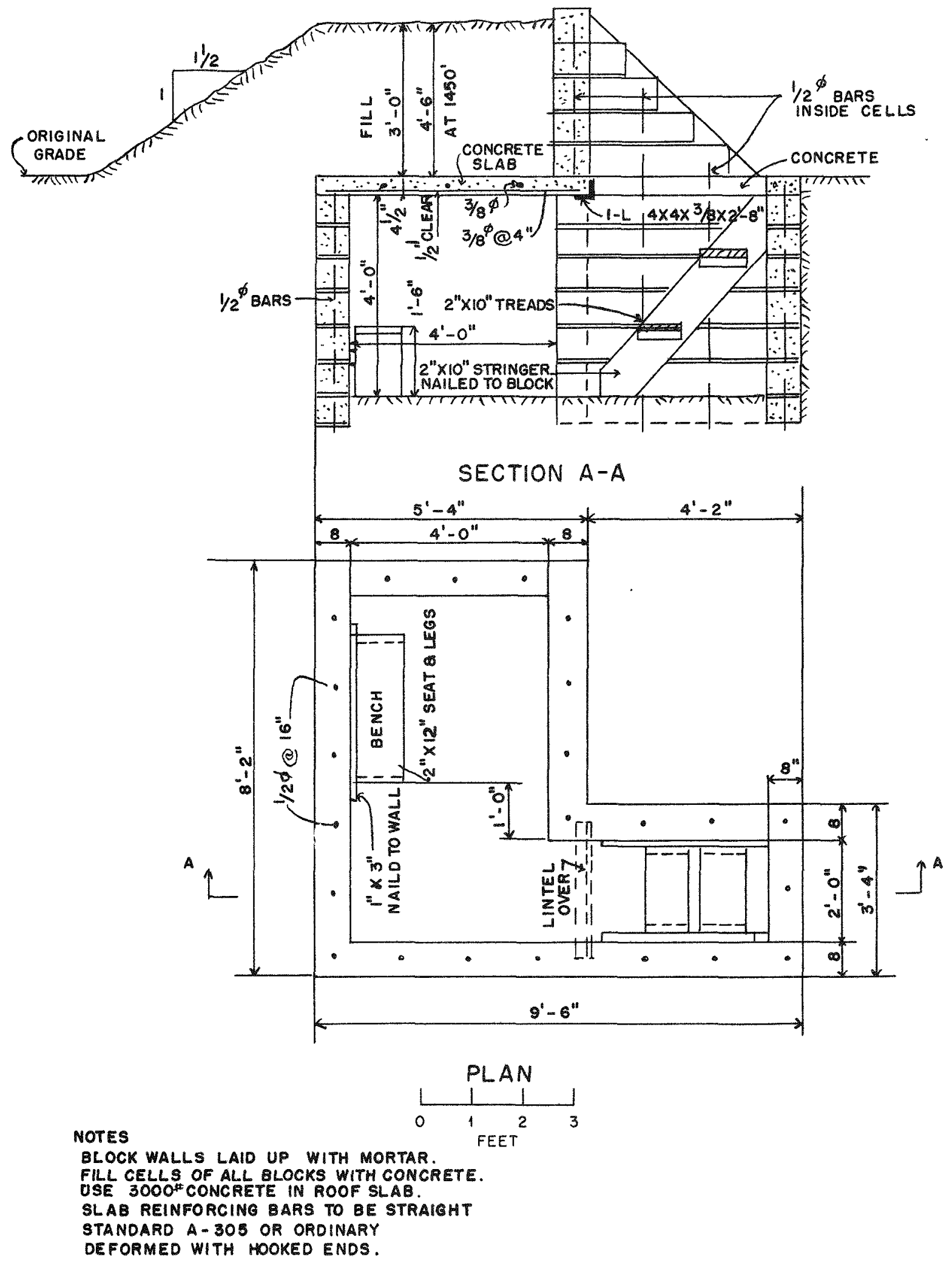

Fig. A.3-Covered trench at 1450,1800 , and $3500 \mathrm{ft}$. 


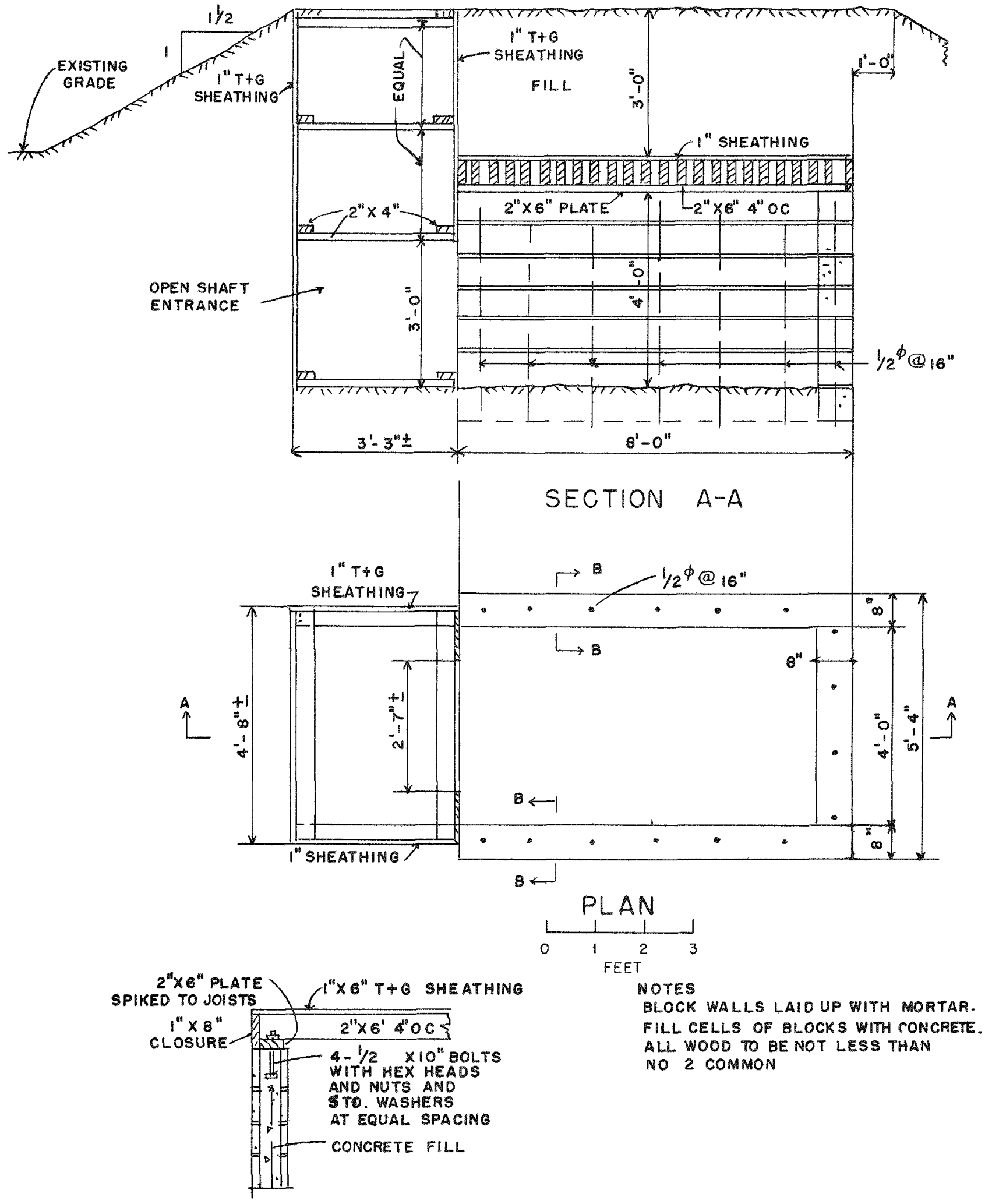

\section{SECTION B-B}

Fig. A.4-Wood-covered trench. 


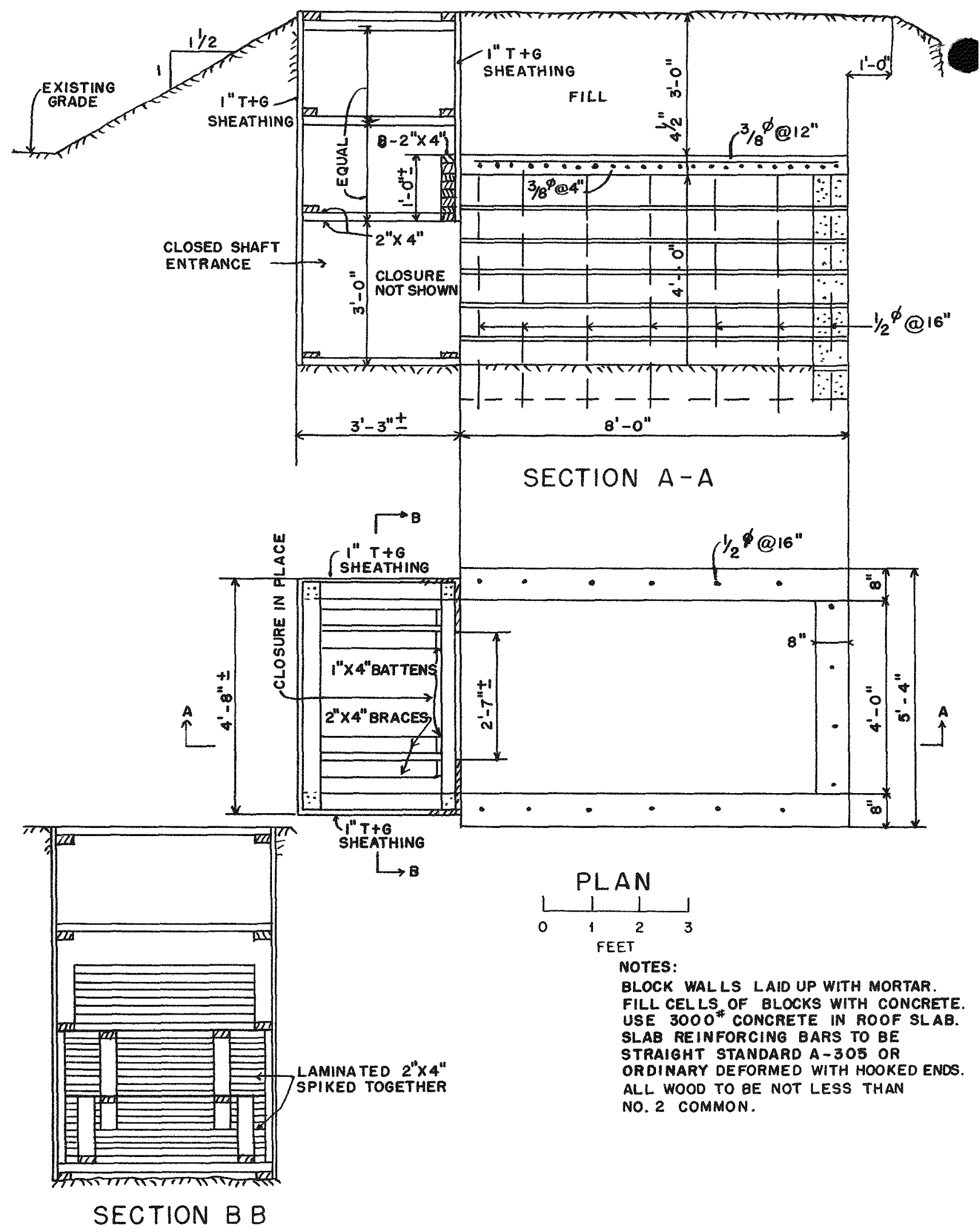

Fig. A.5-Covered trench with closed shaft entrance. 

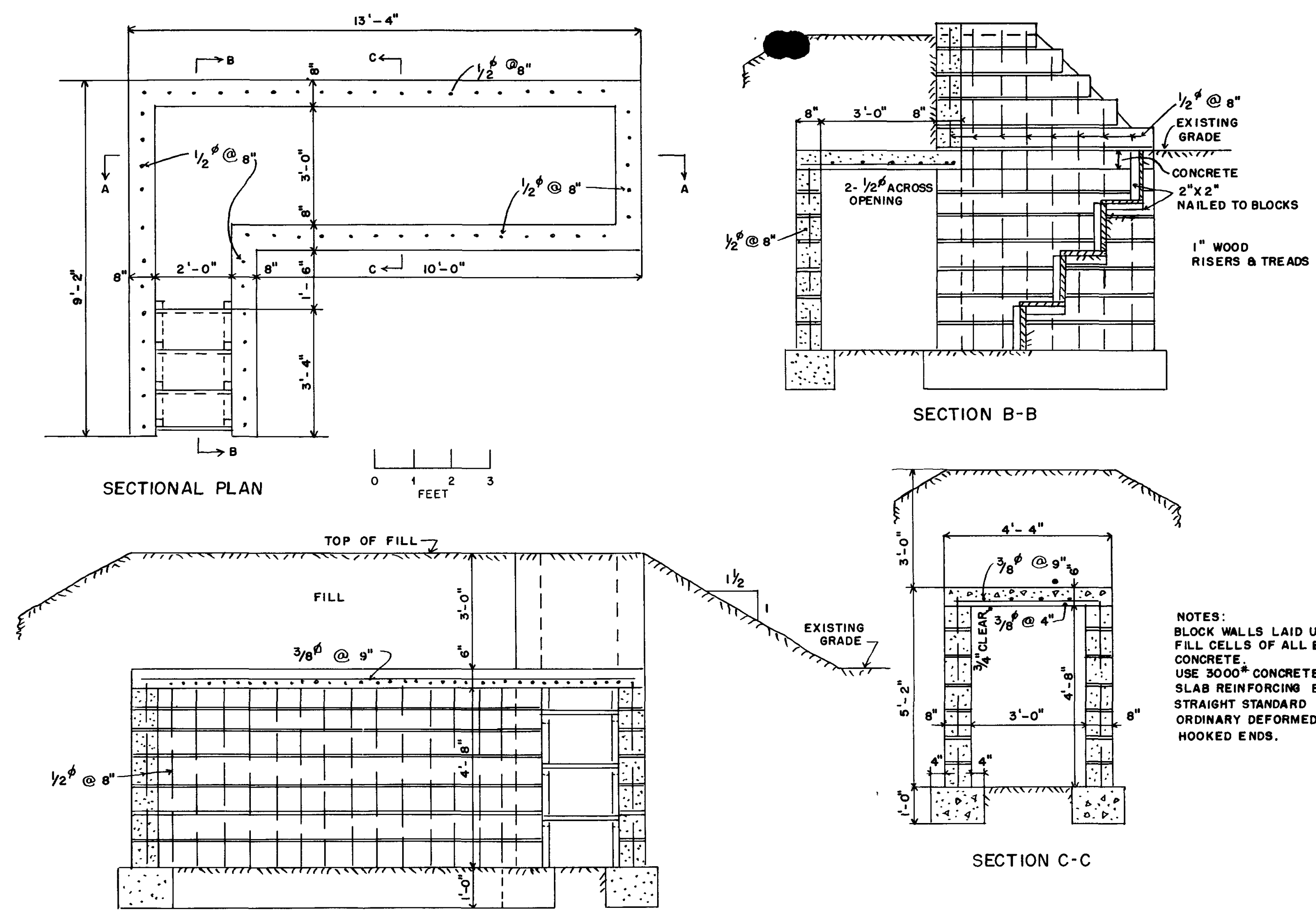

NOTES:

WOCK WALLS LAID UP WITH MORTAR. CONCRETE USE 3000* CONCRETE IN ROOF SLAB. SLAB REINFORCING BARS TO BE STRAIGHT STANDARD A-3O5 OR ORDINAAY DEFORMED WITH HOOKED ENOS.

SECTION A-A 

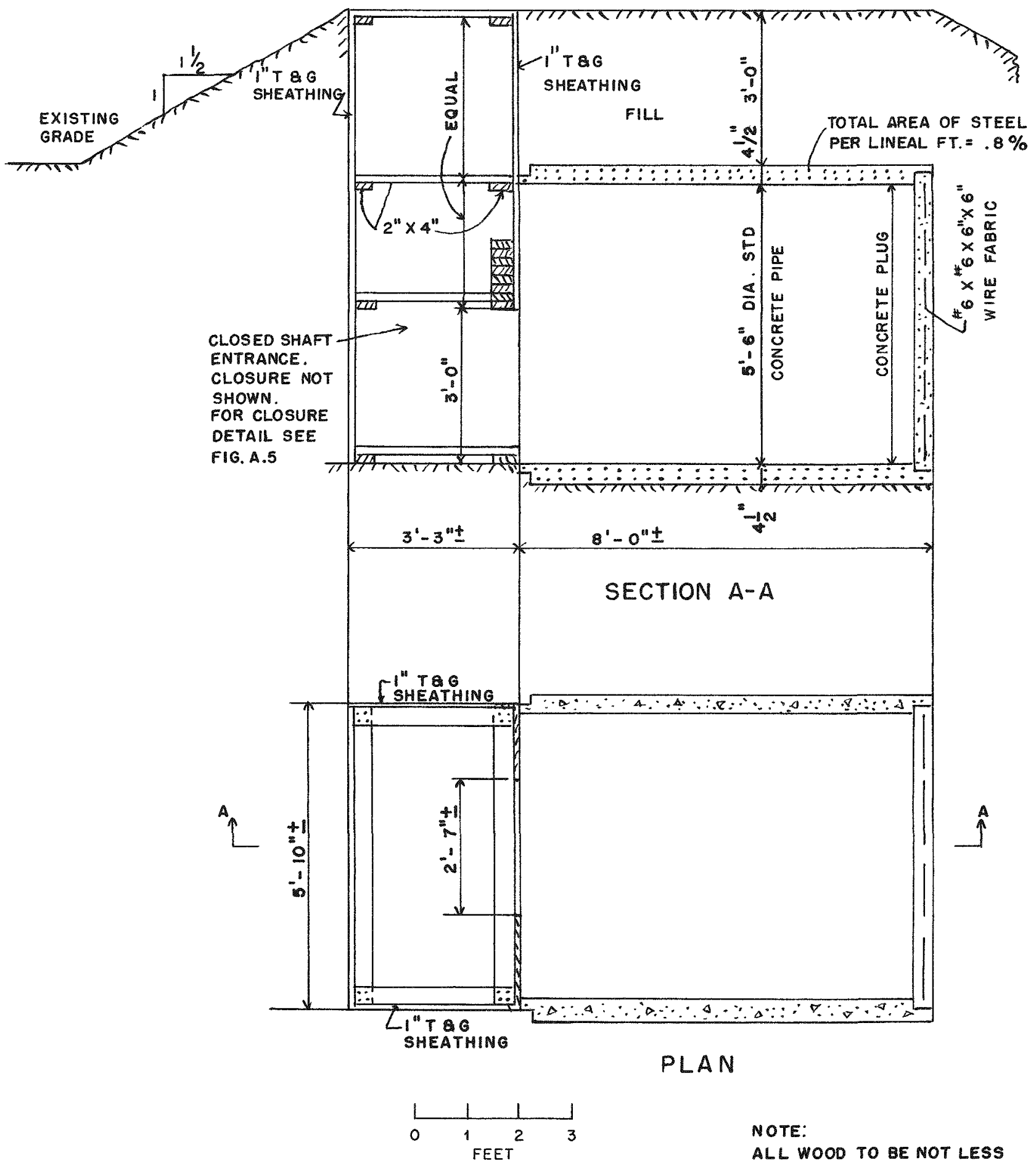

NOTE:

ALL WOOD TO BE NOT LESS THAN NO.2 COMMON.

Fig. A.7-Concrete pipe with closed shaft entrance. 


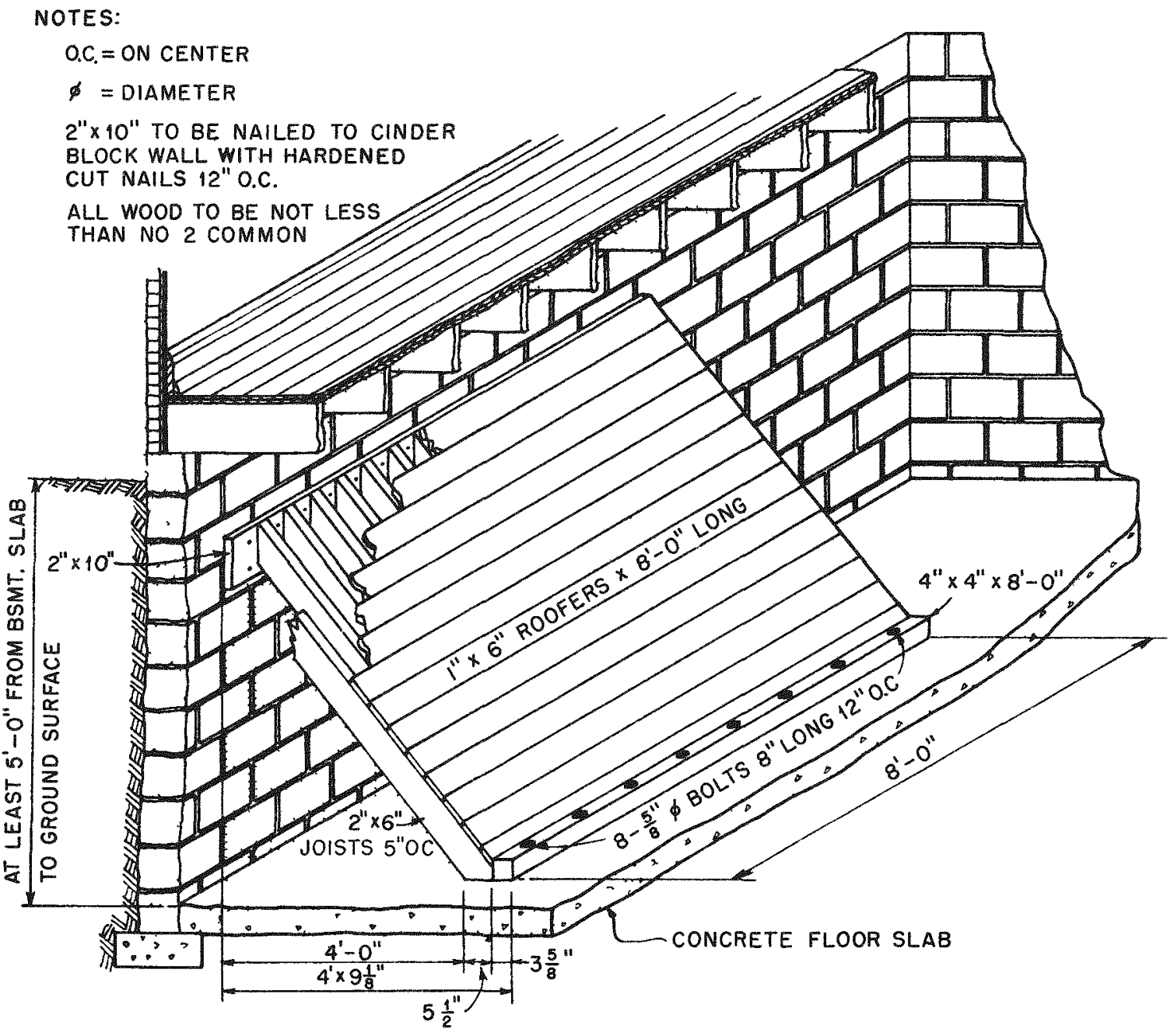

Fig. A.8-Wooden lean-to at 3500 and $7500 \mathrm{ft}$. 


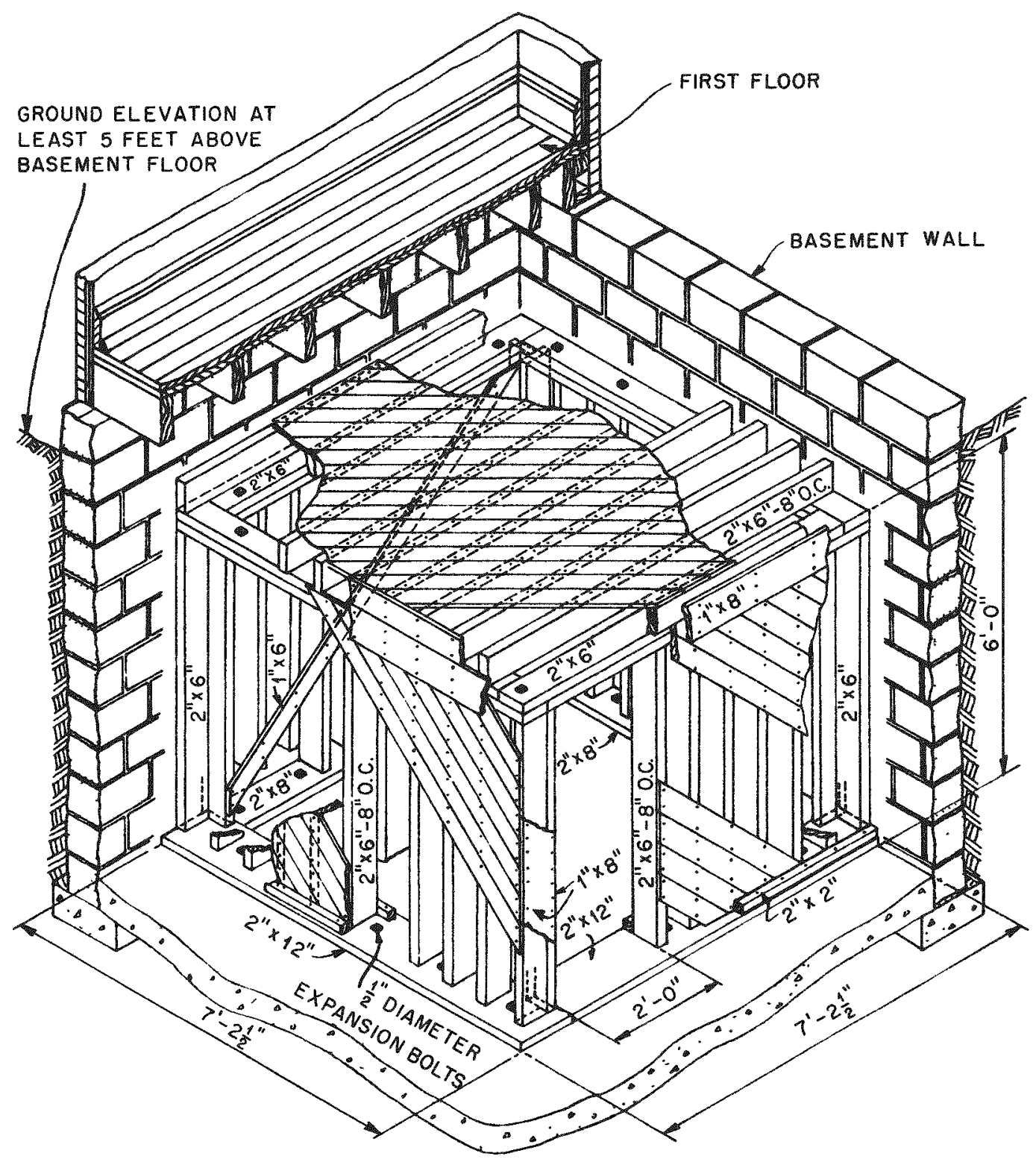

Fig. A.9-Basement corner room at 3500 and $7500 \mathrm{ft}$. All wood to be not less than No. 2 common. Roof to be prefabricated and erected as a unit. 


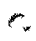

.




\section{DISTRIBUTION}

\section{ARMY ACTIVITTES}

Asst. Chief of Staff, G-1, D/A, Washington 25, D. C., ATTN: Human Relations and Research Board

Asst. Chief of Staff, G-2, D/A, Washington 25, D. C.

Asst. Chief of Staff, G-3, D/A, Washington 25, D. C., A TTN: Dep. CofS, G-3 (RR\&SW)

Asst. Chief of Staff, G-4, D/A, Washington 25, D. C.

Chief of Ordnance, D/A, Washington 25, D. C., ATTN: ORDTX-AR

Chief Signal Officer, D/A, P\&O Division, Washington 25, D. C., ATTN: SIGOP

The Surgeon General, D/A, Washington 25, D. C., ATTN: Chairman, Medical R\&D Board

Chief Chemical Officer, D/A, Washington 25, D. C.

The Quartermaster General, CBR, Liaison Officer, Research and Development Division, D/A, Washington $25, D$. C.

Chief of Engineers, D/A, Washington 25, D. C., ATTN: ENGNB

Chief of Transportation, Military Planning and Intelligence Division, Washington 25, D. C.

Chief, Army Field Forces, Ft. Monroe, Va.

President, Board \#1, OCAFF, Ft. Bragg, N. C.

President, Board \#2, OCAFF, Ft. Knox, Ky.

President, Board \#3, OCAFF, Ft. Benning, Ga.

President, Board \#4, OCAFF, Ft. Bliss, Tex.

Commanding General, First Army, Governor's Island, New York 4, N. Y.

Commanding General, Second A rmy, Ft. George G. Meade, Md.

Commanding General, Third Army, Ft. McPherson, Ga., ATTN: ACofS, G-3

Commanding General, Fourth Army, Ft. Sam Houston, Tex., ATTN: G-3 Section

Commanding General, Fifth Army, 1660 E. Hyde Park Blvd., Chicago 15, 11.

Commanding General, Sixth Army, Presidio of San Francisco, Calif., ATTN: AMGCT-4

Commanding General, U. S. Army Caribbean, Ft. Amador, C. Z., ATTN: Cml. Off.

Commanding General, USARFANT \& MDPR, Ft. Brooke, Puerto Rico

Commanding General, U.S. Forces Austria, APO 168, c/o PM, New York, N. Y., ATTN: ACofS, G-3

Commander-in-Chief, European Command, APO 128, c/o PM, New York, N. Y.

Commander-in-Chief, Far East Command, APO 500, c/o PM, San Francisco, Calif., ATTN: ACofS, J-3

Commanding General, U. S. Army Forces Far East (Main), APO 343, c/o PM, San Francisco, Calif., ATTN: ACofS, J-3

Commanding General, U. S. Army Alaska, APO 942, c/o PM, Seattle, Wash.

Commanding Genera1, U. S. Army Europe, APO 403, c/o PM, New York, N. X., ATTN: OPOT Division, Combat Dev. Br.

Commanding General, U. S. Army Pacific, APO 958, c/o PM, San Francisco, Calif., ATTN: Cml. Off.

Commandant, Command and General Staff College, Ft. Leavenworth, Kan., ATTN: ALLIS(AS)

Commandant, Army War College, Carlisle Barracks, Pa., ATTN: Library

Commandant, The Infantry School, Ft. Benning, Ga., ATTN: C. D. S.

Commandant, The Artillery School, Ft. Sill, Okla.

Commandant, The AA\&GM Branch, The Artillery School, Ft. Bliss, Tex.

1

2

3

5

6-8

9

$10-11$

12-13

14-18

19

20-28

29

30

31

32

33

34

35

36

37

38

39

40

41

42

$43-44$

45

46

$47-48$

49-50

51-52

53-55

56

57

58 
Commandant, The Armored School, Ft. Knox, Ky.

Commanding General, Medical Field Service School, Brooke Army Medical Center, Ft.

Sam Houston, Tex.

Director, Special Weapons Development Office, Ft. Bliss, Tex., ATTN: Lt. Arthur Jaskierny

Commandant, Army Medical Service Graduate School, Walter Reed Army Medical Center, Washington $25, \mathrm{D}$. C.

Superintendent, U. S. Military Academy, West Point, N. Y., ATTN: Professor of Ordnance

Commandant, Chemical Corps School, Chemical Corps Training Command, Ft. McClellan, Ala.

Commanding General, Research and Engineering Command, Army Chemical Center, Md., ATTN: Deputy for RW and Non-Toxic Material

Commanding General, Aberdeen Proving Ground, Md. (inner envelope), ATTN: RD

Control Officer (for Dir., Ballistic Research Labs.)

Commanding General, The Engineer Center, Ft. Belvoir, Va., ATTN: Asst. Commandant, Engineer School

Commanding Officer, Engineer Research and Development Laboratory, Ft. Belvoir, Va., ATTN: Chief, Technical Intelligence Branch

Commanding Officer, Picatinny Arsenal, Dover, N. J., ATTN: ORDBB-TK

Commanding officer, Frankford Arsenal, Philadelphia 37, Pa. (inner envelope), ATTN: RD Control Off.

Commanding Officer, Army Medical Research Laboratory, Ft. Knox, Ky.

Commanding officer, Chemical Corps Chemical and Radiological Laboratory, Army Chemical Center, Md., ATTN: Tech. Library

Commanding Officer, Transportation R\&D Station, Ft. Eustis, Va.

Commanding General. The Transportation Center and Ft. Eustis, Ft. Eustis, Va., ATTN: Military Science and Tactics Board

Director, Technical Documents Center, Evans Signal Laboratory, Belmax, N. J.

Director, Waterways Experiment Station, PO Box 631, Vicksburg, Miss,, ATTN: Library

Director, Operations Research Office, Johns Hopkins University, 6410 Connecticut Ave., Chevy Chase, Md., ATTN: Library

61

62

63

64

$65-66$

$67-68$

$69-71$

72

73

74

75

$76-77$

78

79

80

81

82

\section{NAVY ACTIVITIES}

Chief of Naval Operations, D/N, Washington 25, D. C., ATTN: OP-36

Chief of Naval Operations, D/N, Washington 25, D. C., ATTN: OP-37

Chief of Naval Operations, D/N, Washington 25, D. C., ATTN: OP-374(OEG)

Chief of Naval Operations, D/N, Washington 25, D. C., ATTN: OP-322V

Chief, Bureau of Medicine and Surgery, D/N, Washington 25, D. C., ATTN: Special Weapons Defense Division

Chief, Bureau of Ordnance, D/N, Washington $25, \mathrm{D} . \mathrm{C}$.

Chief of Naval Personnel, D/N, Washington 25, D. C.

Chief, Bureau of Ships, D/N, Washington 25, D. C., ATTN: Code 348

Chief, Bureau of Yards and Docks, D/N, Washington 25, D. C., ATTN: P-312

Chief, Bureau of Supplies and Accounts, D/N, Washington 25, D. C.

Chief, Bureau of Aeronautics, $D / N$, Washington 25, D. C.

Chief of Naval Research, D/N, Washington 25, D. C., ATTN: Lt.(jg) F. McKee, USN

Commander-in-Chief, U. S. Pacific Fleet, Fleet Post Office, San Francisco, Calif.

Commander-in-Chief, U. S. Atlantic Fleet, U. S. Naval Base, Norfolk 11, Va.

Commandant, U. S. Marine Corps, Washington 25, D. C., ATTN: AO3H

President, U. S. Naval War College, Newport, R. 1 .

Superintendent, U. S. Naval Postgraduate School, Monterey, Calif.

Commanding Officer, U. S. Naval Schools Command, U. S. Naval Station, Treasure Island, San Francisco, Calif.

Director, USMC Development Center, USMC Schools, Quantico, Va., ATTN: Tactics Board

Director, USMC Development Center, USMC Schools, Quantico, Va., ATTN: Equipment Board

Commanding Officer, U. S. Fleet Training Center, Naval Base, Norfolk 11, Va, ATTN: Special Weapons School

Commanding Officer, U. S. Fleet Training Center, Naval Station, San Diego 36, Calif., ATTN: (SPWP School)
$83-84$

85

86

87

88

89

90

91

92

93

$94-95$

96

$97-98$

$99-100$

$101-104$

105

106

107

108

109

110

$111-112$

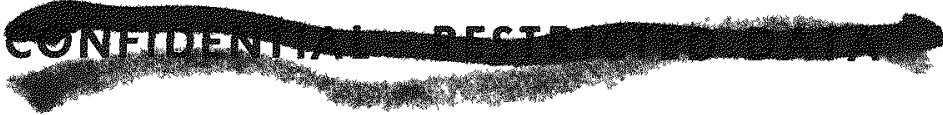


Commanding Officer, Air Development Squadron 5, VX-5, U. S. Naval Air Station, Moffett Field, Calif.

Commanding Officer, U. S. Naval Damage Control Training Center, Naval Base, Philadelphia 12, Pa., ATTN: ABC Defense Course

Commanding Officer, U. S. Naval Unit, Chemical Corps School, Army Chemical Training Center, Ft. Moclellan, Ala.

Joint Landing Force Board, Marine Barracks, Camp Lejeune, N.C.

Commander, U. S. Naval Ordnance Laboratory, Silver Spring 19, Md., ATTN: EE

Commander, U. S. Naval Ordnance Laboratory, silver Spring 19, Md., ATTN: EH

Commander, U. S. Naval Ordnance Laboratory, Silver Spring 19, Md., ATTN: R

Commander, U. S. Naval Ordnance Test Station, Inyokern, China Lake, Calif.

Officer-in-Charge, U. S. Naval Civil Engineering Research and Evaluation Laboratory, U. S. Naval Construction Battalion Center, Port Hueneme, Calif., ATTN: Code 753

Commanding Officer, U. S. Naval Medical Research Institute, National Naval Medical Center, Bethesda 14, Md.

Director, U. S. Naval Research Laboratory, Washington 25, D. C.

Director, The Material Laboratory, New York Naval Shipyard, Brooklyn, N. Y.

Commanding Officer and Director, U. S. Navy Electronics Laboratory, San Diego 52, Calif., ATTN: Code 4223

Commanding Officer, U. S. Naval Radiological Defense Laboratory, San F rancisco 24, Calif., ATTN: Technical Information Division

Officer-in-Charge, Special Weapons Supply Depot, U. S. Naval Supply Center, Norfolk 11, Va.

Commanding Officer and Director, David W. Taylor Model Basin, Washington 7, D. C., ATTN: Library

Commander, U. S. Naval Air Development Center, Johnsville, $\mathrm{pa}$.

Director, Office of Naval Research Branch Office, 1000 Geary Street, San Francisco, Calif.

Officer-in-Charge, U. S. Naval Clothing Factory, U. S. Naval Supply Activities, New York, 3rd Avenue and 29th Street, Brooklyn, N. Y., ATTN: R\&D Division

\section{AIR FORCE ACTIVITIES}

Asst. for Atomic Energy, Headquarters, USAF, Washington 25, D. C., ATTN: DCS/O

Asst. for Development Planning, Headquarters, USAF, Washington 25, D. C.

Deputy for Materiel Control, Asst, for Materiel Program Control, DCS/M, Headquarters, USAF, Washington 25, D. C., ATTN: AFMPC-AE

Director of Operations, Headquarters, USAF, Washington 25, D. C., ATTN: Operations Analysis

Director of Operations, Headquarters, USAF, Washington 25, D. C.

Director of Plans, Headquarters, USAF, Washington 25, D. C., ATTN: War Plans Division

Directorate of Requirements, Headquarters, USAF, Washington 25, D. C., ATTN: AFDRQ-SA/M

Director of Research and Development, Headquarters, USAF, Washington 25, D. C., ATTN: Combat Components Div.

Director of Intelligence, Headquarters, USAF, Washington 25, D. C., ATTN: AFOIN 1 B2

The Surgeon General, Headquarters, USAF, Washington 25, D. C., ATTN: Bio. Def. Br., Pre. Med. Div.

Asst. Chief of Staff, Intelligence, Headquarters, U. S. Air Forces Europe, APO 633, c/o PM, New York, N. Y., ATTN: Air Intelligence Branch

Commander, 497th Reconnaissance Technical Squadron (Augmented), APO 633, c/o PM, New York, N. Y.

Commander, Far East Air Forces, APO 925, c/o PM, San Francisco, Calif.

Commander, Alaskan Air Command, APO 942, c/o PM, Seattle, Wash., ATTN: AAOTN

Commander, Northeast Air Command, APO 862, c/o PM, New York, N. Y.

Commander, Strategic Air Command, Offutt AFB, Omaha, Neb., ATTN: Special Weapons Branch, Inspection Div., Inspector General

Commander, Tactical Air Command, Langley AFB, Va., ATTN: Documents Security Branch 
Commander, Air Defense Command, Ent AFB, Colo."

Commander, Air Materiel Command, Wright-Patterson AFB, Dayton, O., ATTN: MCAIDS

Commander, Air Materiel Command, Wright-Patterson AFB, Dayton, O., ATTN: MCSW

Commander, Air Training Command, Scott AFB, Belleville, Ill., ATTN: DCS/O GTP

Commander, Air Research and Development Command, PO Box 1395, Baltimore, Md., ATTN: RDDN

Commander, Air Proving Ground Command, Eglin AFB, Fla., ATTN: AG/TRB

Commander, Air University, Maxwell AFB, Ala.

Commander, Flying Training Air Force, Waco, Tex., ATTN: Director of Observer Training

Commander, Crew Training Air Force, Randolph Field, Tex., ATTN: 2GTS, DCS/O

Commander, Headquarters, Technical Training Air Force, Gulfport, Miss., ATTN: TA\&D

Commandant, Air Force School of Aviation Medicine, Randolph AFB, Tex.

Commander, Wright Air Development Center, Wright-Patterson AFB, Dayton, O., ATTN: WCOESP

Commander, Air Force Cambridge Research Center, 230 Albany Street, Cambridge 39, Mass., ATTN: CRW, Atomic Warfare Directorate

Commander, Air Force Cambridge Research Center, 230 Albany Street, Cambridge 39, Mass., ATTN: CRQST-2

Commander, Air Force Special Weapons Center, Kirtland AFB, N. Mex., ATTN: Library

Commandant, USAF Institute of Technology, Wright-Patterson AFB, Dayton, O., ATTN:

Resident College

Commander, Lowry AFB, Denver, Colo., ATTN: Department of Armament Training

Commander, 1009th Special Weapons Squadron, Headquarters, USAF, Washington 25, D. C.

The RAND Corporation, 1700 Main Street, Santa Monica, Calif., ATTN: Nuclear Energy Division

Copy
155
$156-157$
158
159
160
161
$162-163$
$164-171$
172
173
$174-175$
$176-181$
182
183
$184-186$
187
188
189
$190-191$

\section{OTHER DEPARTMENT OF DEFENSE ACTIVITIES}

Executive Secretary, Joint Chiefs of Staff, Washington 25, D. C.

Asst. Secretary of Defense, Research and Development, D/D, Washington 25, D. C.

U. S. National Military Representative, Headquarters, SHAPE, APO 55, c/o PM, New York, N. Y., ATTN: Col. J. P. Healy

Director, Weapons Systems Evaluation Group, OSD, Rm 2E1006, Pentagon, Washington 25, D. C.

Asst. for Civil Defense, OSD, Washington 25, D. C.

Chairman, Armed Services Explosives Safety Board, D/D, Rm 2403, Barton Hall,

Washington 25, D. C.

Executive Secretary, Military Liaison Committee, PO Box 1814, Washington 25, D. C.

Commandant, National War College, Washington 25, D. C., ATTN: Classified Records Library

Commandant, Armed Forces Staff College, Norfolk 11, Va., ATTN: Secretary

Commandant, Industrial College of the Armed Forces, Ft. Lesley J. McNair, Washington 25 , D. C.

Commanding General, Field Command, Armed Forces Special Weapons Project, PO Box 5100, Albuquerque, N. Mex.

Chief, Armed Forces Special Weapons Project, PO Box 2610, Washington 13, D. C.

\section{ATOMIC ENERGY COMMISSION ACTIVITIES}

U. S. Atomic Energy Commission, Classified Technical Library, 1901 Constitution Ave., Washington 25, D. C., ATTN: Mrs. J. M. O'Leary (for DMA)

Los Alamos Scientific Laboratory, Report Library, PO Box 1663, Los Alamos, N. Mex., ATTN: Helen Redman

Sandia Corporation, Classified Document Division, Sandia Base, Albuquerque, N. Mex., ATTN: Martin Lucero

University of California Radiation Laboratory, PO Box 808, Livermore, Calif., ATTN: Margaret Folden

U. S. Atomic Energy Commission, Classified Technical Library, 1901 Constitution Ave., Washington 25, D. C., ATTN: Mrs. J. M. O'Leary (for DBM)
192

$193-194$

195

196

197

198

199

200

201

202

$203-208$

209-217
$218-220$

$221-223$

$224-238$

$239-240$

$241-245$

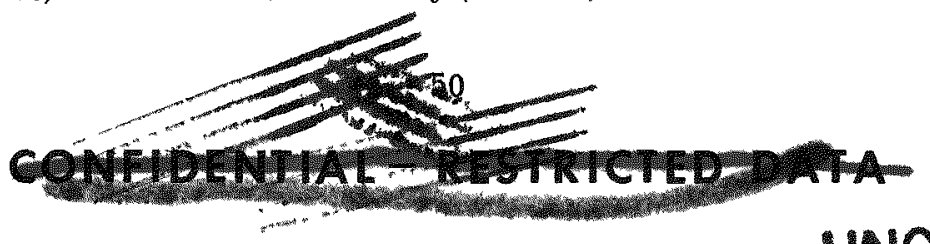




\section{1}

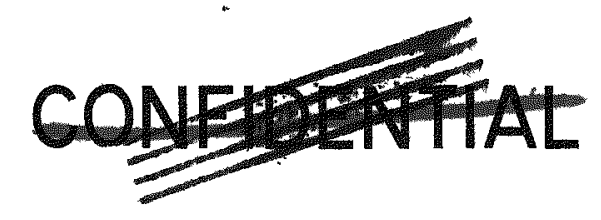

UNCLASSIFIED

Copy

U. S. Atomic Energy Commission, Classified Technical Library, 1901 Constitution Ave., Washington 25, D. C., ATTN: Mrs. J. M. O'Leary (for Director, CETG)

Weapon Data Section, Technical Information Service, Oak Ridge, Tenn.

246-24.

Technical Information Service, Oak Ridge, Tenn. (surplus)

FEDERAL CIVIL DEFENSE ADMINISTRATION

Administrator, Federal Civil Defense Administration, Washington 25, D. C., ATTN:

Paul s. Cooper, Security Division

$336-345$

51

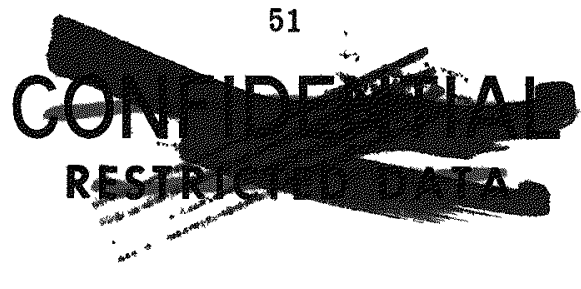

AEC, Oak Rrdge, Tenn., W23014 